OPEN ACCESS

Edited by:

Samuel Abiven,

University of Zurich, Switzerland

Reviewed by:

Alejandro Mateos-Rivera, University of Bergen, Norway

Anja Miltner,

Das Helmholtz-Zentrum für

Umweltforschung, Germany

*Correspondence:

James A. Bradley

jbradley8365@gmail.com

Specialty section: This article was submitted to

Biogeoscience,

a section of the journal

Frontiers in Earth Science

Received: 13 January 2017

Accepted: 07 March 2017

Published: 03 April 2017

Citation:

Bradley JA, Anesio AM and Arndt S (2017) Microbial and Biogeochemical

Dynamics in Glacier Forefields Are

Sensitive to Century-Scale Climate and Anthropogenic Change.

Front. Earth Sci. 5:26.

doi: 10.3389/feart.2017.00026

\section{Microbial and Biogeochemical Dynamics in Glacier Forefields Are Sensitive to Century-Scale Climate and Anthropogenic Change}

\author{
James A. Bradley ${ }^{1,2 *}$, Alexandre M. Anesio ${ }^{2}$ and Sandra Arndt ${ }^{2,3}$ \\ ${ }^{1}$ Department of Earth Sciences, University of Southern California, Los Angeles, CA, USA, ${ }^{2}$ School of Geographical Sciences, \\ University of Bristol, Bristol, UK, ${ }^{3}$ Department of Earth and Environmental Sciences, Université Libre de Bruxelles, Brussels, \\ Belgium
}

The recent retreat of glaciers and ice sheets as a result of global warming exposes forefield soils that are rapidly colonized by microbes. These ecosystems are dominant in high-latitude carbon and nutrient cycles as microbial activity drives biogeochemical transformations within these newly exposed soils. Despite this, little is known about the response of these emerging ecosystems and associated biogeochemical cycles to projected changes in environmental factors due to human impacts. Here, we applied the model SHIMMER to quantitatively explore the sensitivity of biogeochemical dynamics in the forefield of Midtre Lovénbreen, Svalbard, to future changes in climate and anthropogenic forcings including soil temperature, snow cover, and nutrient and organic substrate deposition. Model results indicated that the rapid warming of the Arctic, as well as an increased deposition of organic carbon and nutrients, may impact primary microbial colonizers in Arctic soils. Warming and increased snow-free conditions resulted in enhanced bacterial production and an accumulation of biomass that was sustained throughout 200 years of soil development. Nitrogen deposition stimulated growth during the first 50 years of soil development following exposure. Increased deposition of organic carbon sustained higher rates of bacterial production and heterotrophic respiration leading to decreases in net ecosystem production and thus net $\mathrm{CO}_{2}$ efflux from soils. Pioneer microbial communities were particularly susceptible to future changes. All future climate simulations encouraged a switch from allochthonously-dominated young soils ( $<40$ years) to microbially-dominated older soils, due to enhanced heterotrophic degradation of organic matter. Critically, this drove remineralisation and increased nutrient availability. Overall, we show that human activity, especially the burning of fossil fuels and the enhanced deposition of nitrogen and organic carbon, has the potential to considerably affect the biogeochemical development of recently exposed Arctic soils in the present day and for centuries into the future. These effects must be acknowledged when attempting to make accurate predictions of the future fate of Arctic soils that are exposed over large expanses of presently ice-covered regions.

Keywords: SHIMMER, glacier forefield, microbial dynamics, Arctic soils, climate change 


\section{INTRODUCTION}

Over the past century, the Arctic mean surface air temperature has increased at a rate twice as fast as the global mean and is predicted to warm a further $>4^{\circ} \mathrm{C}$ by 2,100 (Stocker et al., 2013). The observed warming has been accompanied by alarming changes in ice cover, increasing length of glacier melt seasons, and changing precipitation patterns and hydrology (Macdonald et al., 2005). These changes to the physical environment exert cascading effects on Arctic carbon and nutrient dynamics with potentially important, yet underexplored implications for both Arctic ecosystems (Kirchman et al., 2009), as well as global climate (Serreze et al., 2000; Screen and Simmonds, 2010; Stocker et al., 2013). Specifically, ecosystems in Polar regions are thought to be among the most vulnerable to global climate change, due to the adaptation of microbial processes to extreme environmental conditions (Vincent, 2010), and the vulnerability of Polar regions to tipping points (Lenton, 2012). However, there is high uncertainty in the future ecosystem response to predicted Arctic warming (Ciais et al., 2013). Warming of Arctic soils may increase soil respiration and thus $\mathrm{CO}_{2}$ fluxes to the atmosphere, thereby contributing to a positive feedback effect (Billings, 1987; Oechel et al., 1993; Goulden et al., 1998). On the other hand, there is also evidence that Arctic ecosystems in particular may acclimatize to warming over decadal timescales (Oechel et al., 2000). Assessing the potential implications of accelerated climate change in Polar regions on regional and global biogeochemical cycles and the climate system requires a better quantitative understanding of Arctic ecosystems, as well as predictions of their response to ongoing climate change.

Glacier forefields are one of the most intriguing ecosystems in the Arctic as they act as pioneer sites for ecosystem development and soil formation. The retreat of glaciers since the end of the Little Ice Age has led to the emergence of terrestrial landscapes that were previously locked underneath ice (Paul et al., 2011). Glacier forefields act as bioreactors and intermediates between the icy biome (Anesio and Laybourn-Parry, 2012) and downstream ecosystems (Fountain et al., 2004, 2008; Kastovska et al., 2005; Mindl et al., 2007). The physical, geochemical and biological development of exposed soils following glacier retreat have been studied using chronosequence approaches (Bradley et al., 2014 and references therein). Decades of empirical research in glacier forefields has shown that microbes support enhanced weathering rates, the development of complex community structures, the colonization of plants, as well as the physical process of soil formation (Schulz et al., 2013; Bradley et al., 2014). More recently, data derived from field campaigns in the Alps, the Canadian Arctic, and Svalbard, as well as laboratory experiments, were integrated with numerical modeling using the Soil biogeocHemIcal Model for Microbial Ecosystem Response (SHIMMER) to explore microbial dynamics and nutrient fluxes along soil chronosequences (Bradley et al., 2015, 2016b). This integrated model-data approach revealed that autotrophic and heterotrophic biomass has likely accumulated in the forefield of Midtre Lovénbreen glacier (Svalbard) over the last century. Low measured microbial growth efficiency had a potentially important role for nutrient accumulation by enhancing the degradation of organic matter (Bradley et al., 2016b). In addition, simulation results emphasized that microbial communities play a key role in fixing and recycling carbon and nutrients. Furthermore, results indicated that both allochthonous carbon inputs, as well as microbial necromass, are important in sustaining a pool of organic material in older soils, that feeds heterotrophic bacteria.

There are relatively few studies that have explored the effect of environmental factors, such as temperature, snow cover and nutrient supply on microbial dynamics in developing forefield soils. These mostly empirical investigations have correlated microclimatic environments and weather-related seasonal variations with distinct patterns of microbial diversity (Lazzaro et al., 2015) and demonstrated that allochthonous nutrient deposition stimulates microbial activity (Brankatschk et al., 2011; Goransson et al., 2011). Whilst these experiments and observations provide important insights, they often explore only the short-term (seasonal) response to changes in one single environmental factor for a spatially discreet geographical location and thus do not allow for assessment of the mid-term (decadal) to long-term (century) response of the system to holistic environmental perturbations. As such, little is known about the influence of ongoing and projected Arctic environmental change on microbial dynamics and the resulting implications for carbon and nutrients imported and exported from these environments.

In this respect, a mathematical model, which is constructed on the basis of current mechanistic knowledge and tested against experimental datasets, is a powerful means to assess the potential, long-term response of microbial and biogeochemical dynamics to projected climate changes, using a scenario-based approach (Bradley et al., 2016a). Here, we used the novel numerical model SHIMMER (Bradley et al., 2015, 2016b) to quantitatively predict the response of the microbial community as well as the implications for carbon and nutrient transformations and fluxes in the forefield of the Midtre Lovénbreen glacier (Svalbard) over climate-relevant time periods (decades to centuries). To assess the induced changes, simulation results of (1) a baseline scenario that has previously been calibrated (Bradley et al., 2016b) are compared to five different anthropogenic change scenarios: (2) increased soil temperature, (3) increased soil temperature and earlier spring snow melt, (4) increased deposition of reactive nitrogen, (5) increased deposition of organic carbon, and (6) a combination of all of these factors. Finally, regional implications of projected changes are discussed on the basis of model results.

\section{METHODS}

\section{Study Site}

We focused the investigation on the forefield of Midtre Lovénbreen, an Arctic polythermal valley glacier on the Kongsfjorden, Western Svalbard $\left(78^{\circ} 55^{\prime} \mathrm{N}, 12^{\circ} 10^{\prime} \mathrm{E}\right)$. This glacier forefield has previously been the subject of an integrated and comprehensive field, laboratory and modeling study (Bradley et al., 2016b). In the framework of this study, determination of model sensitivity helped identify critical model parameters, that were then constrained by laboratory measurement of bacterial growth rates, growth efficiencies and temperature response for 
this specific habitat, and helped refine model predictions. The Midtre Lovénbreen catchment is roughly $5 \mathrm{~km}$ East of $\mathrm{Ny}$ Ålesund, where several long-term monitoring programs and weather stations provide contextual information and forcing data. Midtre Lovénbreen has experienced negative mass balance throughout much of the Twentieth Century. Since the end of the Little Ice Age maximum (in the 1900s) in Svalbard, the glacier snout has retreated considerably in response to a warming of mean annual temperatures (Lefauconnier et al., 1999). This retreat continues to the present day (Fleming et al., 1997; Moreau et al., 2008). The regional climate is predominantly influenced by the North Atlantic Current, resulting in a maritime Polar climate that is uncharacteristically mild for the region. The Midtre Lovénbreen catchment falls within the tundra zone in Svalbard, amid the areas that are the richest in fauna and flora. The glacier forefield zone, however, is extremely sparsely vegetated, mostly consisting of lichens, Dryas octopetala and Saxifraga oppositifolia in microlocal habitats in soil that has been exposed for roughly 100 years (Moreau et al., 2008). Nearby cliffs are heavily populated with nesting birds, and the tundra is frequented by mammals including the Svalbard reindeer, the Arctic fox and the polar bear. Snow-cover persists over winter (typically from October until June), containing biologically significant concentrations of nutrients and organic material (Larose et al., 2013a,b).

\section{The SHIMMER Model}

The numerical model SHIMMER (Bradley et al., 2015) is a novel microbial-biogeochemical model designed to simulate the initial stages of microbial community establishment during soil development in glacier forefields. SHIMMER has been previously developed and successfully used to quantify microbial and nutrient dynamics in a number of contrasting forefields in Switzerland, Canada, and Svalbard (Bradley et al., 2015, 2016b). It thus represents an ideal tool to quantitatively explore the potential response of these systems to projected climate change. The model is zero-dimensional and explicitly resolves the evolving dynamics of microbial biomass, labile and refractory organic substrate $\left(S_{1}\right.$ and $S_{2}$ respectively), dissolved inorganic nitrogen (DIN) and dissolved inorganic phosphorus (DIP) along a chronosequence (Table S1). Microbes are categorized according to function: autotrophs $\left(\mathrm{A}_{1-3}\right)$ and heterotrophs $\left(\mathrm{H}_{1-3}\right)$ are further subdivided into glacial microbes $\left(\mathrm{A}_{1}\right.$ and $\left.\mathrm{H}_{1}\right)$, soil microbes $\left(\mathrm{A}_{2}\right.$ and $\left.\mathrm{H}_{2}\right)$ and nitrogen-fixing microbes $\left(\mathrm{A}_{3}\right.$ and $\left.\mathrm{H}_{3}\right)$. Transformations in substrate and nutrients due to autotrophic and heterotrophic production and respiration, microbial growth, death and predation, exopolymetric-substance (EPS) production, and nitrogen fixation are also explicitly resolved (Figure 1). The following external forcings drive and regulate the model dynamics: (1) PAR (wavelength of approximately $400-700 \mathrm{~nm}$ ) ( $\left.\mathrm{W} \mathrm{m}^{-2}\right)$, (2) snow depth $(\mathrm{m}),(3)$ soil temperature $\left({ }^{\circ} \mathrm{C}\right)$, and (4) allochthonous inputs of organic material, DIN and DIP (provided in $\mu \mathrm{g} \mathrm{g}^{-1} \mathrm{~d}^{-1}$ ). The Supplementary Information contains a detailed description of the model set-up used in this study, including a list of initial conditions (Table S1) and parameter values (Table S2).

\section{Model Scenarios}

Here, we used SHIMMER to quantitatively explore the response of the Midtre Lovénbreen glacier forefield to a number of different climate scenarios, described in detail below. A baseline scenario ("BASE") and five future climate change scenarios were designed to explore the response of microbial and biogeochemical dynamics to projected changes in the physical environment ("TEMP" and "TEMP\&SNOW"), perturbations of external carbon and nitrogen inputs ("NITRO" and "SUBS"), as well as a combined scenario ("COMB"). This approach allows exploration into the individual effects of climate change driven variations in external forcings, as well as to assess the potential combined effects of these climate-driven variations on the forefield dynamics. Simulated future climate scenarios are described and evaluated as stand-alone simulations, or relative to the control model simulation run with baseline forcings.

\section{"BASE" Scenario: Baseline Forcings}

The baseline simulation was set up exactly as the optimized model simulation presented in Bradley et al. (2016b). Briefly, meteorological forcings were constrained by daily observations for the entire year 2013 and remained unchanged for the duration of the model run (Figure 2). Averaged daily soil temperature (at $1 \mathrm{~cm}$ depth) and PAR for 2013 were provided by the Alfred Wegener Institute for Polar and Marine Research (AWI) from the permafrost observatory near Ny-Ålesund, Svalbard, and the AWI meteorological station near Ny-Ålesund, Svalbard, respectively. Averaged daily snow depth for $2009-2013$ is provided by the Norwegian Meteorological Institute (eKlima). The presence of snow on the ground attenuates sunlight and inhibits PAR from reaching the soil surface. This was accounted for in preprocessing of forcing data. Light attenuation was estimated according to the equation:

$$
n=n_{0} e^{-m x}
$$

Whereby $n$ is the irradiance ( $\mathrm{W} \mathrm{m}^{-2}$ ), $x$ is the snow depth (m) and $m$ is the extinction coefficient for snow (Greenfell and Maykut, 1977; Bradley et al., 2015). Due to its high latitude, the study site experiences continual daylight for much of the summer and continual darkness for much of the winter. Forcing data was provided as daily averages, and linear interpolation was used between any (very infrequent) missing data points. Averaged daily allochthonous nutrients and carbon inputs were estimated based on the best available budget estimates of catchment hydrology and nutrients for Midtre Lovénbreen presented in Hodson et al. (2005), described and used in Bradley et al. (2016b) and also summarized in the Supplementary Information (Tables S3, S4).

\section{"TEMP" Scenario: Increased Soil Temperature}

Climate change is amplified in the Arctic region, and as such Svalbard is particularly susceptible to climate warming due to its northerly latitude and its geographical location at the northernmost reach of the North Atlantic Current (Overland et al., 2014). Air temperature warming at Kongsfjorden, the site of the Midtre Lovénbreen glacier, has occurred in the last two decades and is expected to continue with present emissions rates 


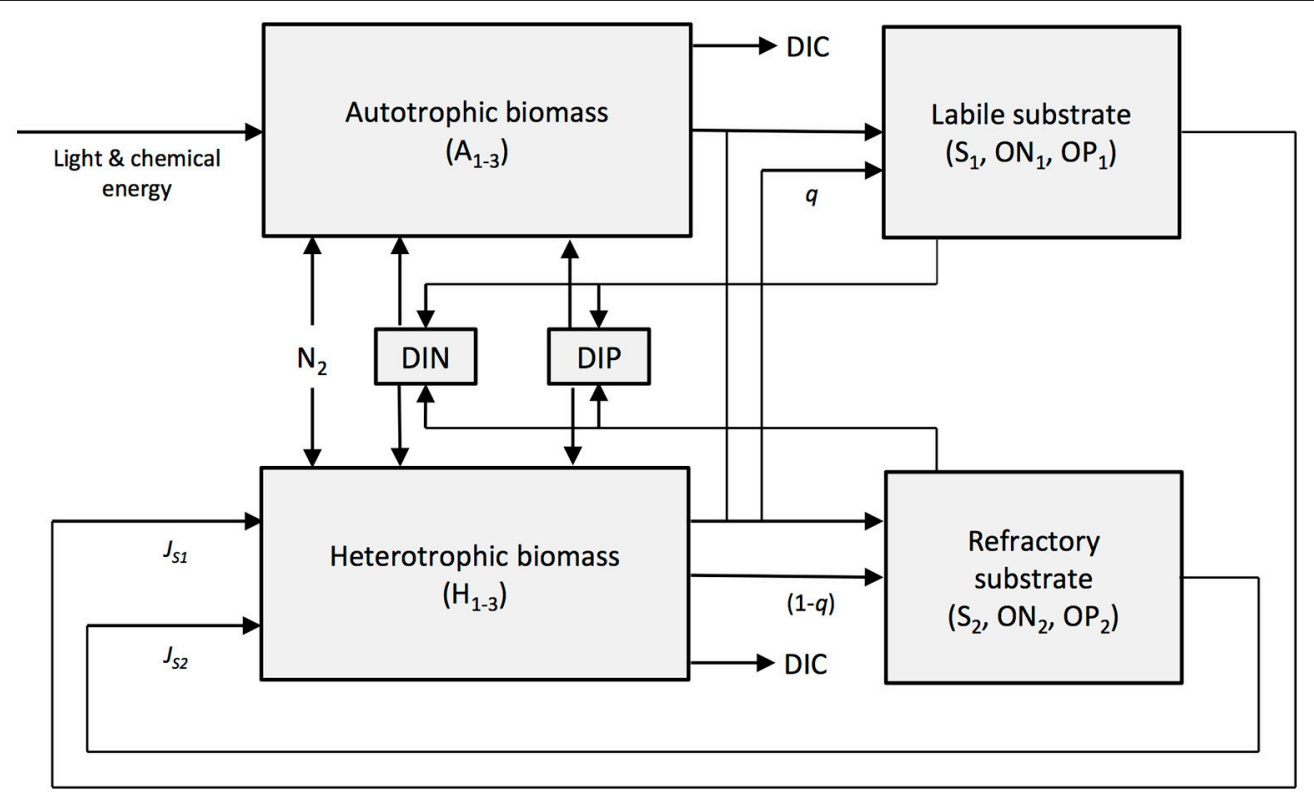

FIGURE 1 | A conceptual model showing the components and transfers of SHIMMER. State variables are indicated with shading. Image reproduced from Bradley et al. (2015).

(Maturilli et al., 2015). A very strong winter warming trend has been identified alongside positive linear temperature trends for spring, summer, and autumn (Forland et al., 2011). Therefore, TEMP explores the effect of increasing soil temperatures on the microbial and biogeochemical dynamics in the forefield. For TEMP, we used predicted monthly surface air temperature anomalies from the year 2000 to 2100 (relative to the 19812005 period mean) based on climate model predictions for the Arctic region $\left(60-90^{\circ} \mathrm{N}\right)$ presented in Overland et al. (2014) (Table 1). Two end-member IPCC Representative Concentration Pathways (RCPs) that cover the entire range of potential warming are investigated: (1) the RCP 4.5 scenario ("mitigation" scenario) whereby $\mathrm{CO}_{2}$ emissions increase only slightly before decline commences around 2040; and (2) RCP 8.5 scenario ("business-as-usual"/"extreme" scenario), the most extreme climate scenario whereby emissions are projected to increase and $\mathrm{CO}_{2}$ concentration is projected to rise above $1,370 \mathrm{ppm}$ by 2100 (Moss et al., 2010). Predicted surface air temperature warming was taken specifically from the Svalbard region in climate model predictions (Overland et al., 2014). We assumed that surface air temperature warming equated directly to an equal increase in soil temperature whenever there is an absence of snow cover $(<1 \mathrm{~cm})$. The changes (compared to the baseline scenario) to soil temperature (scenario RCP 8.5), snow depth and PAR after 100 years are illustrated in Figure 2.

\section{"TEMP\&SNOW" Scenario: Increased Soil Temperature and Earlier Spring Snow Melt}

Observations indicate that there has been a persistent increase in the duration of snow-free conditions across Eurasia and North America for the past three decades, at a rate of 5 to 6 days per decade (Anisimov et al., 2007). TEMP\&SNOW thus explores the combined effect of increasing soil temperatures and earlier spring melt on the microbial and biogeochemical dynamics in the forefield. For TEMP\&SNOW (RCP 4.5 and RCP 8.5), we prescribed an earlier spring snow melt rate of 1 day every 2 years to reflect observations (Anisimov et al., 2007), alongside soil temperature increases based on the (1) RCP 4.5 and (2) RCP 8.5 pathways explored in TEMP. For new snow-free days, soil temperature was set to the projected air temperature (based on RCP 4.5 and RCP 8.5). PAR attenuation was re-calculated for every simulated day to account for the new snow depth. The changes after 100 years (compared to the baseline scenario) are illustrated in Figure 2.

\section{“NITRO" Scenario: Increased DIN Input}

In recent decades, human activity has profoundly changed the biogeochemical cycling of reactive nitrogen in Arctic regions (Roberts et al., 2010). $\mathrm{NO}$ and $\mathrm{NO}_{2}$ are released predominantly by burning fossil fuels (90\%) and application of fertilizer (10\%) (Geng et al., 2014). Enhanced winter transport of polluted air from both Europe and Russia has led to increased nitrogen deposition in the Arctic (Eneroth et al., 2003). Although a number of studies have attempted to assess the effect of increased nitrogen deposition on carbon cycling at both the regional as well as global scales (Holland et al., 1997; Nadelhoffer et al., 1999; Zaehle and Friend, 2010; Mahowald, 2011), no estimates of future deposition fluxes to the Artic, let alone their implications for Arctic carbon and nutrient cycling, currently exist. Local anthropogenic inputs of nitrogen to the biosphere can lead to changes in the productivity of nitrogen deficient ecosystems, that directly impact carbon uptake rates (Galloway et al., 2008). Evidence for anthropogenic nitrogen inputs to cryospheric ecosystems include northern hemisphere ice core 

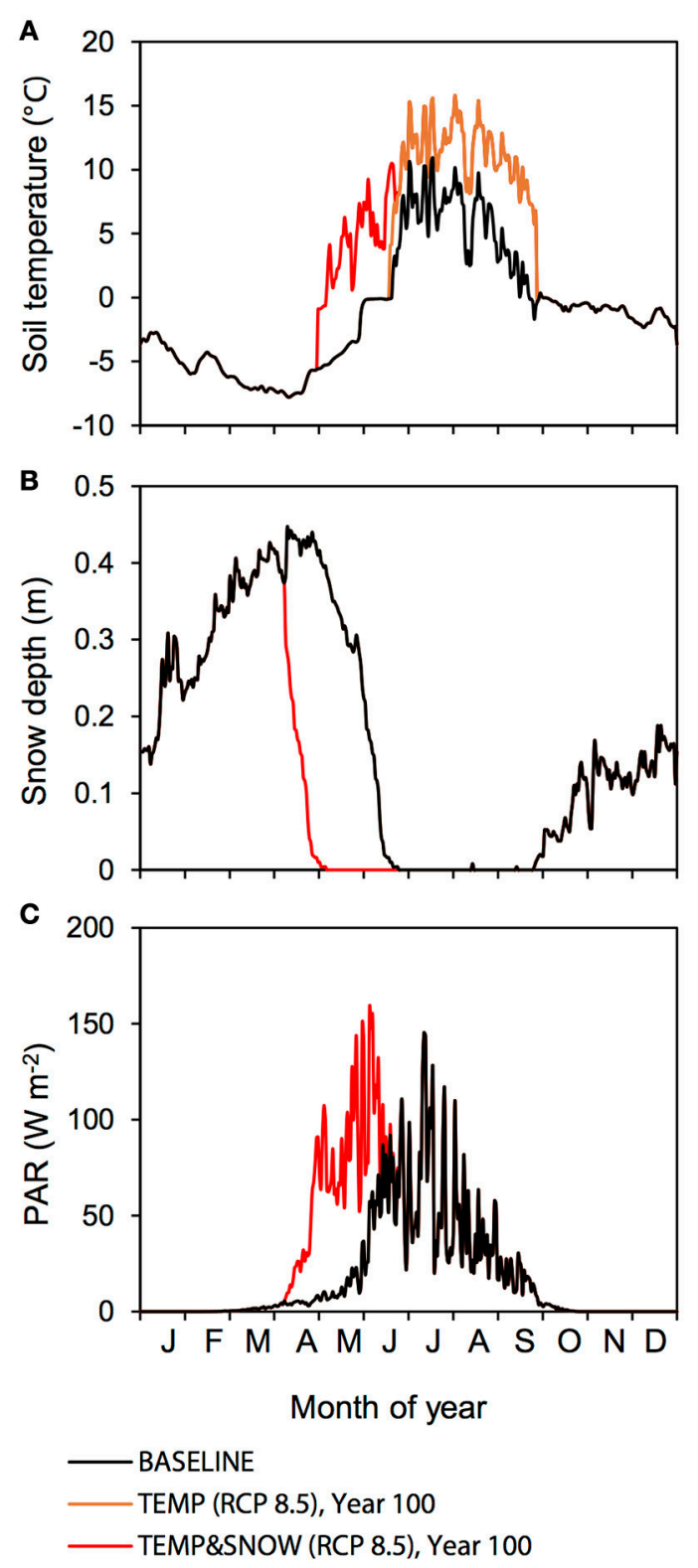

FIGURE 2 | Baseline and manipulated meteorological forcings at Midtre Lovénbreen glacier forefield. (A) Soil temperature, (B) snow depth, and (C) PAR. Baseline forcings are indicated in black. Forcings for TEMP (RCP 8.5) (orange) and TEMPandSNOW (RCP 8.5) (red) are shown for year 100.

records (Goto-Azuma and Koerner, 2001; Isaksson et al., 2003; Hastings et al., 2009), Svalbard lake sediments (Birks et al., 2004), and field-based snowpack measurements and modeling (Bjorkman et al., 2013; Kuhnel et al., 2013). Differences in the magnitude and timing of periodic increases in nitrate deposition in the Arctic can be attributed to different source regions and pathways of pollutants (Goto-Azuma and Koerner, 2001; Geng et al., 2014). However, there is considerable uncertainty in predicting the magnitude of future reactive nitrogen deposition. Ice core analyses from the Greenland Summit station has shown
TABLE 1 | Prescribed soil temperature increases for RCP 4.5 and 8.5 (from Overland et al., 2014).

\begin{tabular}{lcc}
\hline Month & \multicolumn{2}{c}{ Temperature increase $\left({ }^{\circ} \mathbf{C}_{\text { year }}{ }^{-1}\right)$} \\
\cline { 2 - 3 } & RCP 4.5 & RCP 8.5 \\
\hline January & 0.051 & 0.114 \\
February & 0.042 & 0.103 \\
March & 0.037 & 0.084 \\
April & 0.028 & 0.065 \\
May & 0.019 & 0.047 \\
June & 0.019 & 0.042 \\
July & 0.019 & 0.047 \\
August & 0.028 & 0.056 \\
September & 0.037 & 0.075 \\
October & 0.056 & 0.093 \\
November & 0.065 & 0.121 \\
December & 0.065 & 0.131 \\
\hline
\end{tabular}

a doubling of $\mathrm{NO}_{3}^{-}$concentrations in the last century, and a negative ${ }^{15} \mathrm{~N}$ stable isotope excursion suggesting this increase is associated with anthropogenic sources (Geng et al., 2014). Furthermore, climatological data from Svalbard has shown that strong depositional events sometimes lead to reactive nitrogen deposition fluxes up to 3 times higher than the annual mean deposition flux (Kuhnel et al., 2013). However, in recent decades (since 1970), nitrate deposition in the Arctic has stabilized due to North American air pollution mitigation strategies (Geng et al., 2014). However, despite recent mitigation policies, increased shipping in the Arctic due to sea-ice decline may further increase local reactive nitrogen inputs (Peters et al., 2011; Eckhardt et al., 2013). Therefore, overall trends of reactive deposition are uncertain, resulting from the interplay of emissions, atmospheric transport, chemistry, precipitation, and snowpack processes (Kuhnel et al., 2011). The NITRO simulation is thus designed to explore the effect of increased DIN input on the microbial and biogeochemical dynamics of the forefield. To account for the possible future range of DIN deposition in the Arctic due to anthropogenic factors, we carry out multiple simulations from 1.0 (BASE) to 4.0 times (extreme) nominal deposition flux. This range encapsulates the variability from observations from both ice core records (up to 2 times) (Geng et al., 2014) and climatological data (up to 3 times) (Kuhnel et al., 2011) and for the possible occurrence of "extreme" (up to 4 times) nitrogen deposition events in the future.

\section{"SUBS" Scenario: Increased Input of Organic \\ Substrate}

Forefield soils accumulate organic carbon from autochthonous production, allochthonous deposition, and ancient sources that are mobilized during glacier retreat (Schulz et al., 2013). Similarly, glacier surfaces accumulate organic carbon from biological activity (e.g., in situ primary production) and the deposition of allochthonous organic material from terrestrial or anthropogenic sources (Hood and Berner, 2009; Singer et al., 2012; Stibal et al., 2012). It has been suggested that the 
allochthonous flux of organic carbon to glacier forefields could increase over the next two centuries due to (1) increased glacier runoff and thus increased flux of organic carbon from glacier surfaces to the pro-glacial zone (Foreman et al., 2007; Hood et al., 2015), (2) a longer residence time of liquid water in the glacial snowpack supporting higher growth and carbon fixation rates of snow algae (Morgan-Kiss et al., 2006; Stibal et al., 2007; Takeuchi et al., 2009; Lutz et al., 2015), (3) the invasion of non-native birds and mammals (Jonsdottir, 2005; Kelly et al., 2010; Miller and Ruiz, 2014; Ware et al., 2014), (4) the invasion of new plant species as human activity and tourism increases (Ware et al., 2014), and (5) an enhanced input of feces-derived organic material to soils from increasing populations of Barnacle Geese, Reindeer herds and other biota in Svalbard in response to climate warming (Michelutti et al., 2009; Moe et al., 2009; Luoto et al., 2015). However, there is considerable uncertainty in predicting the magnitude of future substrate deposition and, to our knowledge, no studies have made direct predictions based on estimations or empirical data. Therefore, we have simulated a range of possible future scenarios from present day deposition rates increasing up to 4 times present day for the following reasons: (1) the chosen range encapsulates a substantial increase in organic matter deposition compared to the present day, and (2) it is consistent with the range investigated for DIN deposition, allowing for comparative sensitivity analysis between the two forcing scenarios.

\section{"COMB" Scenario: Warming, Snow Melt, and Nitrogen and Substrate Deposition}

COMB is based on a combination of all extreme scenarios to explore the maximum effect of climate change on microbial communities and biogeochemical dynamics in glacier forefield soils. Thus, COMB assumes:

- Soil temperature prescribed according to RCP 8.5-based predictions.

- Snow melting prescribed according to TEMP\&SNOW.

- Allochthonous inputs of DIN and substrate prescribed to a maximum of 4 times nominal values.

\section{RESULTS AND DISCUSSION}

\section{Baseline Scenario: Microbial and Biogeochemical Dynamics in the Midtre Lovénbreen Forefield}

Figure 3 summarizes the simulated evolution of microbial and biogeochemical dynamics in the Midtre Lovénbreen forefield over a period of 200 years. Simulation results show that, while both autotrophic and heterotrophic biomass accumulated in the forefield, the microbial community was dominated by autotrophs (Figures 3A,B). The increase in biomass for all functional groups was first characterized by a lag phase (years 0-40), due to the slow accumulation of biomass from extremely low inocula concentrations. This was followed by a rapid growth phase (years 40-80), with exponential growth in bacterial populations due to increased biomass and nutrient availability. Finally, from year 80 onwards, microbial growth slowed down due to limiting organic carbon availability in forefield soils, since soil organic carbon stocks were mostly refractory (Figure 3C). During initial soil development (20-50 years), nitrogen-fixers $\left(\mathrm{A}_{3}\right.$ and $\left.\mathrm{H}_{3}\right)$ experienced more rapid growth than other functional groups because of their ability to overcome DIN-limitation by fixing atmospheric nitrogen. All other functional groups $\left(\mathrm{A}_{1-2}\right.$ and $\mathrm{H}_{1-2}$ ) were co-limited by DIN and DIP and therefore their biomass accumulated at a slower rate.

Carbon and nutrient dynamics were mainly controlled by allochthonous inputs during the lag phase (0-40 years), whereas microbial dynamics became the main control on carbon and nutrient stocks during and after the rapid growth phase (4080 years). Refractory organic carbon $\left(S_{2}\right)$ accumulated over the entire simulation period (Figure $3 \mathrm{C}$ ), predominantly by contributions from allochthonous deposition $(>50 \%)$ in years $0-114$, and necromass ( $>50 \%$ ) from year 114 onwards. In contrast, the concentration of labile substrate $\left(S_{1}\right)$ increased slightly during the initial lag period (year $0-40$ ), followed by a depletion due to rapid heterotrophic growth during years 50100 (Figure 3C). Simulation results show that DIN and DIP concentrations increased from trace quantities $\left(<4 \mu \mathrm{g} \mathrm{g}^{-1}\right.$ and $<2 \mu \mathrm{g} \mathrm{g}^{-1}$ respectively) to $>157 \mu \mathrm{g} \mathrm{g}^{-1}$ and $>201 \mu \mathrm{g} \mathrm{g}^{-1}$ respectively over two centuries. Figure $4 \mathrm{~A}$ illustrates that the observed increase in nitrogen concentrations was mainly driven by allochthonous deposition $(>50 \%)$ in young soils (years $0-$ 38 ), while internal recycling by heterotrophic activity increased nitrogen stocks in older soils (contributing 90-95\% in years 60 200). Similarly, Figure 5A shows that allochthonous deposition dominated DIP accumulation (up to 99\%) from years 0-66, while heterotrophic recycling contributed $48-58 \%$ of total DIP input after year 66. Simulation results thus indicate that the switch from an allochthonous-controlled system to a microbialcontrolled system was triggered by nutrient availability from external sources, and further enhanced by nutrients that are increasingly derived from heterotrophic remineralisation of necromass-supplied organic matter (Figure 3C).

The glacier forefield was characterized by negative net ecosystem production rates $(\mathrm{NEP}=$ total heterotrophic respiration-total net autotrophic $\mathrm{CO}_{2}$ fixation) over the entire simulation period (Figure 3D), despite high autotrophic biomass. The magnitude of NEP was highly variable over the simulated period. In the initial phase, low rates of autotrophic and heterotrophic activity resulted in NEP close to zero. Between years 60 and 90, an increase in heterotrophic growth and degradation rates, supported mainly by initial stocks of organic carbon and the accumulation of allochthonous labile and refractory organic carbon, led to a decrease in NEP (< $-8 \mu \mathrm{g} \mathrm{C} \mathrm{g}^{-1} \mathrm{y}^{-1}$ ). Subsequently (years 110-200) NEP rates stabilized at $-4 \mu \mathrm{g} \mathrm{C} \mathrm{g}^{-1} \mathrm{y}^{-1}\left( \pm 1 \mu \mathrm{g} \mathrm{C} \mathrm{g} \mathrm{g}^{-1}\right)$ as bacterial activity remained relatively constant. During this phase, nutrient limitation was alleviated (due to the accumulation of recycled DIN and DIP in the soil) and heterotrophic growth became limited by available organic matter (Figure 3C). In a previous study, measured heterotrophic growth efficiency for these soils was extremely low (Bradley et al., 2016b) (Table S2). Thus, the observed net heterotrophy and the associated net release of $\mathrm{CO}_{2}$ to the atmosphere was mainly driven by substantial 

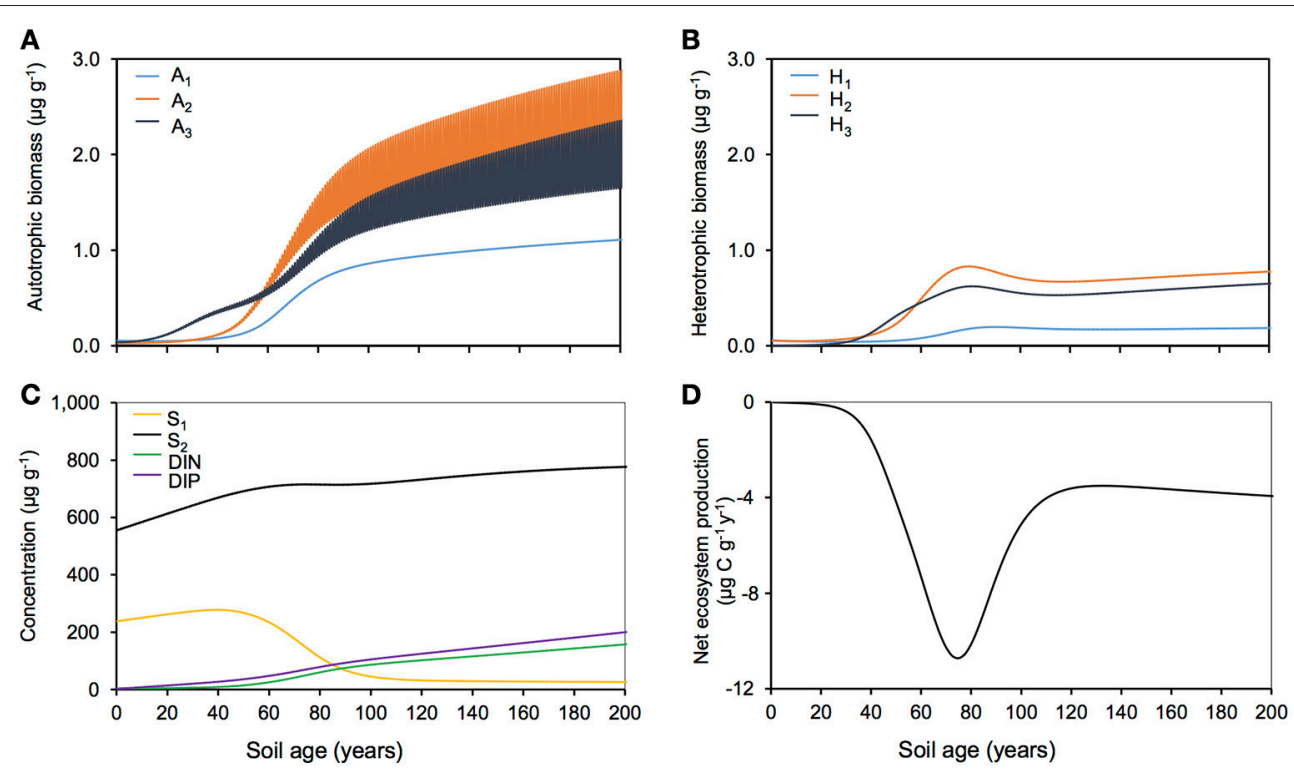

FIGURE 3 | Baseline simulation for Midtre Lovénbreen glacier forefield. Modeled (A) autotrophic biomass, (B) heterotrophic biomass, (C) carbon substrate and nutrients and (D) net ecosystem production with nominal (baseline) forcings.

degradation of initial carbon stocks and was sustained by allochthonous carbon inputs. Modeling therefore suggests that heterotrophic processing of initial and allochthonous inputs of organic substrate exert a major control on glacier forefield biogeochemistry. Predicted carbon fluxes in the Midtre Lovénbreen forefield are corroborated by data from the forefield of the Damma Glacier (Switzerland). Evidence from the Damma Glacier suggests high rates of $\mathrm{CO}_{2}$ efflux from soils, particularly in the later stages of development (soil age $>110$ years) (Guelland et al., 2013b), and also suggest that organic matter becomes increasingly refractory in the later stages of development due to continual re-working and cycling by microbial communities (Goransson et al., 2011). However, empirical evidence from Midtre Lovénbreen is currently lacking, and this should be a particular focus of future experimental efforts. Heterotrophic activity in glacier forefield soils is sensitive to environmental conditions (Brankatschk et al., 2011; Goransson et al., 2011), indicating that projected future changes in temperature, snow cover and allochthonous inputs might have an important impact on regional carbon and nutrient cycling. The following sections explore the potential response of the Midtre Lovénbreen forefield to such changes.

\section{Effect of Projected Climate Change on Microbial Dynamics in the Midtre Lovénbreen Forefield General Response}

Figure 6 summarizes the simulated response (relative to the baseline (BASE) scenario) of each individual functional group to each tested scenario of environmental change. Simulation results show that the entire forefield microbial community was responsive to the environmental changes imposed in all future climate scenarios investigated. Model results show a peak in percentage biomass increase (relative to the baseline simulation) for all functional groups in response to all climatological forcings occurred between years 30 and 80 , after which the percentage biomass increase stabilized at lower values. The observed peaks varied in height (abundance) and width (duration) depending on the specific forcing investigated and the functional group of interest, but in general they coincided with the exponential (rapid) growth phase of bacteria (see Figure 3). In younger soils, nutrient availability generally limited microbial growth (Bradley et al., 2014, 2016b). Thus, alleviating growth limitations by increasing allochthonous inputs or, to a lesser extent, improving physical conditions, triggered a pronounced growth response. Model results also show that generic soil autotrophs and heterotrophs ( $\mathrm{A}_{2}$ and $\mathrm{H}_{2}$ respectively) reacted more strongly to an improvement in growth conditions than glacial bacteria $\left(A_{1}\right.$ and $\mathrm{H}_{1}$ ), which are better adapted to growing in oligotrophic low nutrient conditions, and nitrogen fixers $\left(\mathrm{A}_{3}\right.$ and $\left.\mathrm{H}_{3}\right)$, which can source atmospheric nitrogen $\left(\mathrm{N}_{2}\right)$ in place of DIN. In older soils (year 80 onwards), bacterial abundance was high and the rate of new biomass accumulation was relatively low. These older soils generally contained nutrient concentrations well above limiting concentrations ( $\mathrm{K}_{\mathrm{N}}$ and $\mathrm{K}_{\mathrm{P}}$, Table S2) resulting in a stabilization of the system that approaches its ecological climax (although at greater abundance than in the baseline simulation). Therefore, in older forefield soils, the response of microbial biomass to environmental perturbations was weaker than in younger soils.

\section{Response to Increased Temperature and Decreased Snow Cover (TEMP and TEMP\&SNOW)}

Warming promoted soil conditions that were more favorable to autotrophic and heterotrophic growth. Similarly, earlier snow melt allowed for a longer autotrophic growth season 


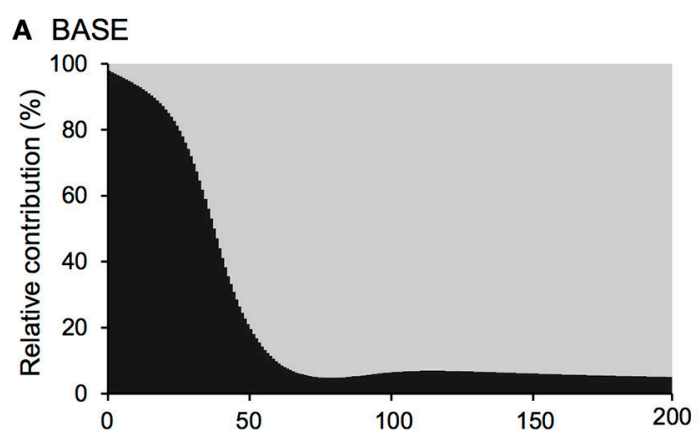

C TEMP\&SNOW (RCP 8.5)

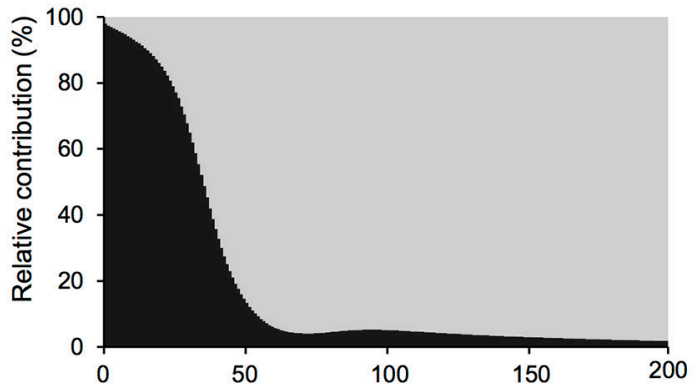

E SUBS (4.0)

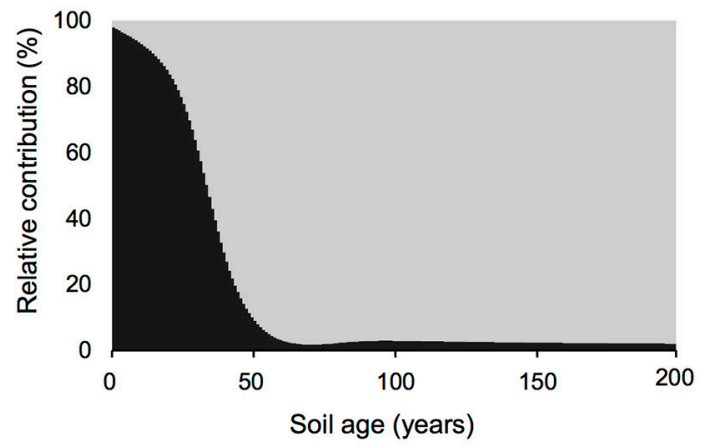

- Allochthonous deposition

Remineralized
B TEMP (RCP 8.5)

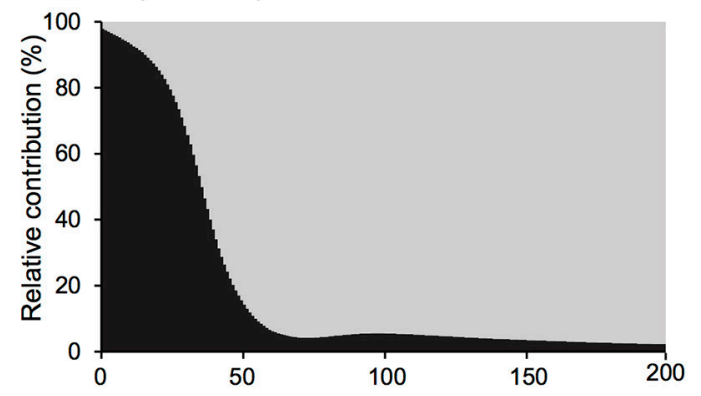

D NITRO (4.0)

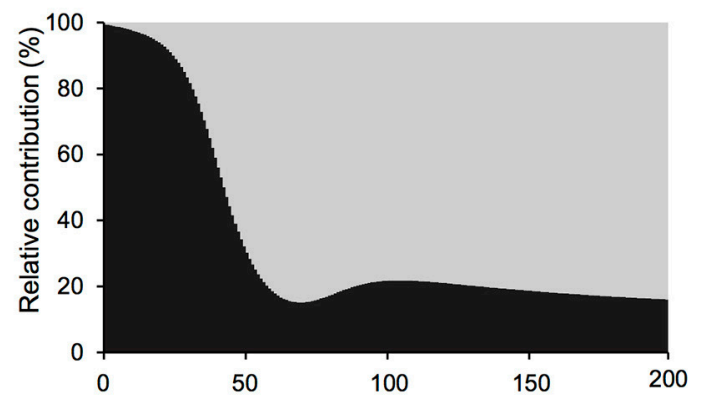

F $\quad$ COMB (4.0)

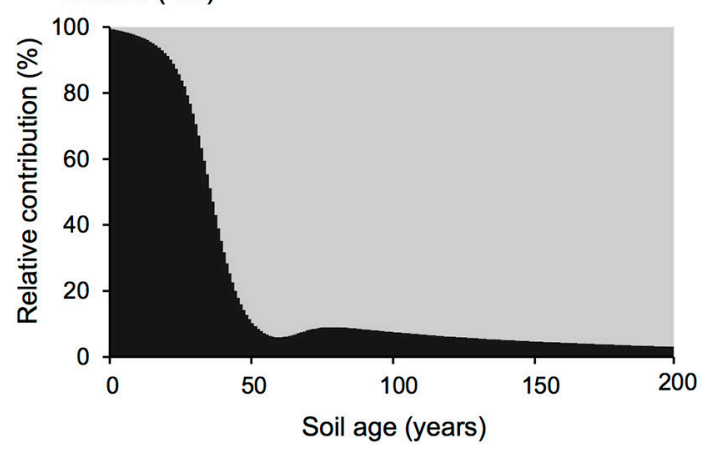

FIGURE 4 | DIN budget. Relative contribution of allochthonous deposition (black) and remineralisation of organic matter (gray) to the DIN pool over 200 years of soil development for (A) BASE, (B) TEMP (RCP 8.5), (C) TEMPandSNOW (RCP 8.5), (D) NITRO (4.0), (E) SUBS (4.0), and (F) COMB (4.0).

due to increased exposure to PAR. Over century time-scales, temperature and snow cover play an important role in microbial community dynamics in glacier forefields. Model results show that the response of autotrophs $\left(\mathrm{A}_{1-3}\right)$ to modeled climatological changes was stronger than the response of heterotrophs $\left(\mathrm{H}_{1-3}\right)$ (Figure 6), suggesting that the positive effect of temperature increase and snow-free conditions on autotrophs did not linearly translate to heterotrophs. This observation can be explained by the reduced availability of labile organic carbon in these simulations, which limited heterotrophic growth. The improved thermal and light conditions induced a stronger long-term response in autotrophic populations (in particular $\mathrm{A}_{2}$ and $\mathrm{A}_{3}$ ) than any other single driver (red line, Figure 6). Furthermore, the effects of temperature on biomass were enhanced with "extreme" temperature warming (RCP 8.5, light blue line, up to $33.9 \%$ increase in total biomass) compared to the "mitigation" climate scenario (RCP 4.5, yellow line, up to $25.0 \%$ ). These trends are supported by empirical observations from soil manipulation experiments suggesting that a positive relationship exists between temperature and observed growth of Arctic and sub-Arctic microbial communities (Callaghan et al., 1999; Yergeau et al., 2012; Sistla et al., 2013; van der Wal and Stien, 2014; Lau et al., 2015; Bradley et al., 2016b; Newsham et al., 2016). 

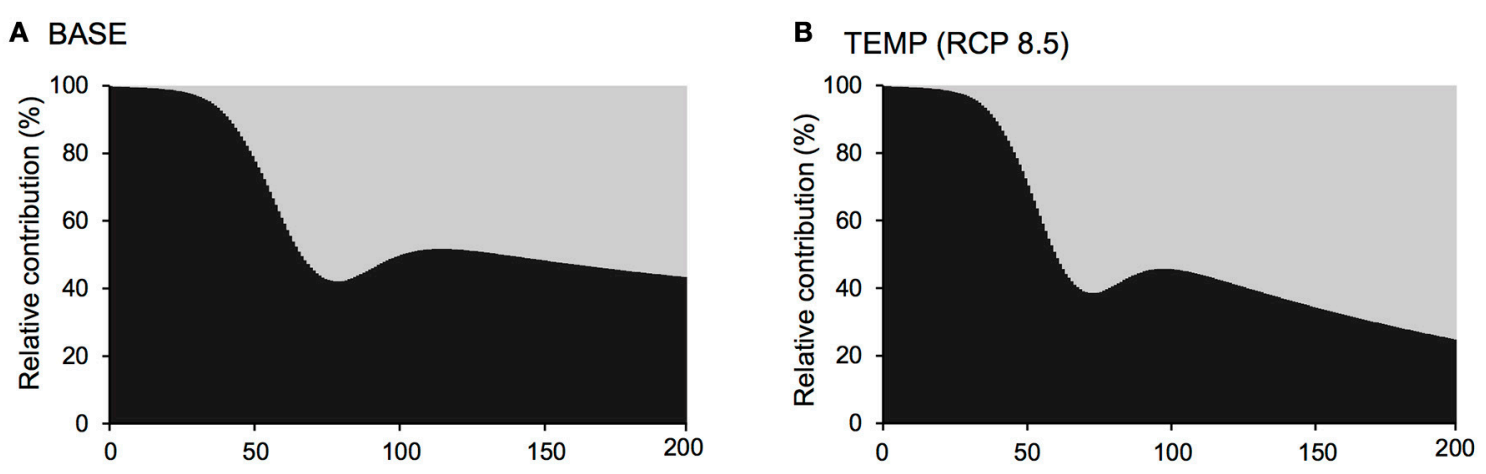

\section{TEMP\&SNOW (RCP 8.5)}
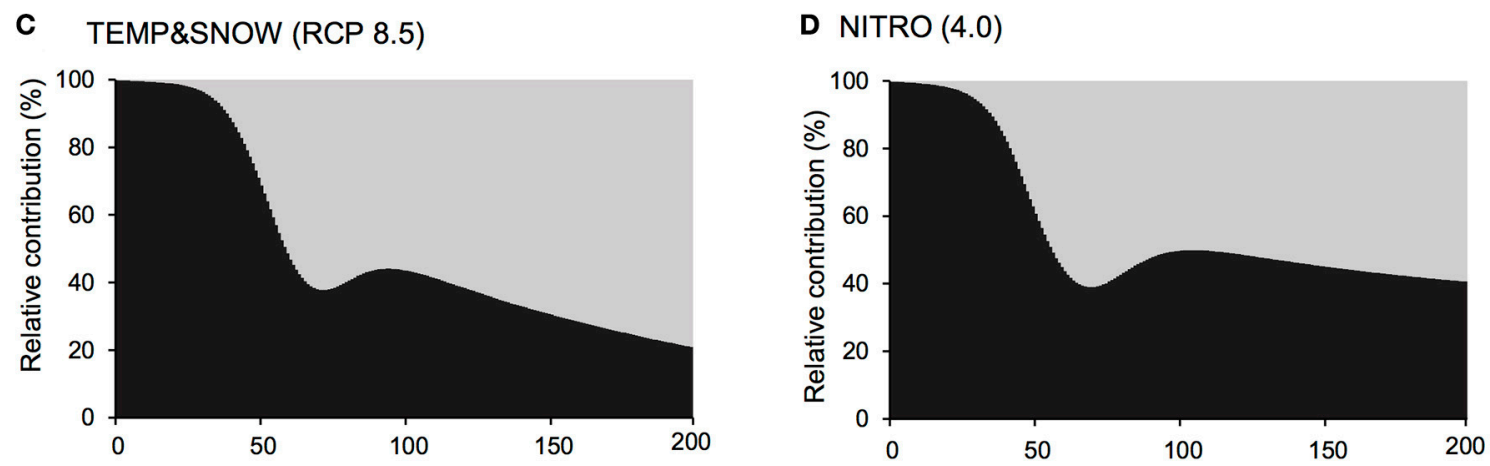

E SUBS (4.0)

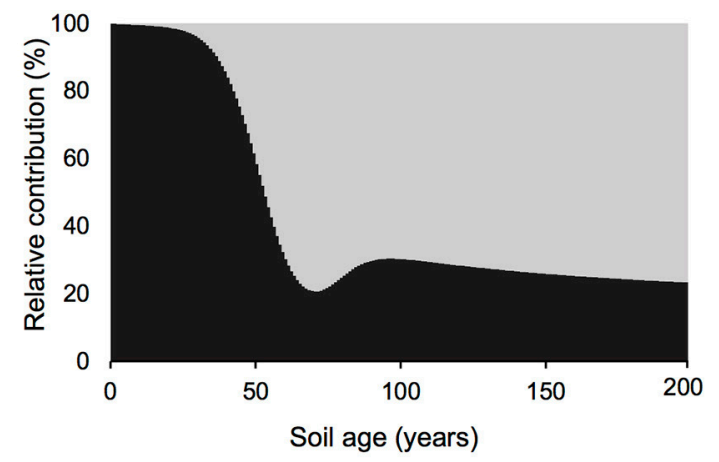

F $\operatorname{COMB}(4.0)$

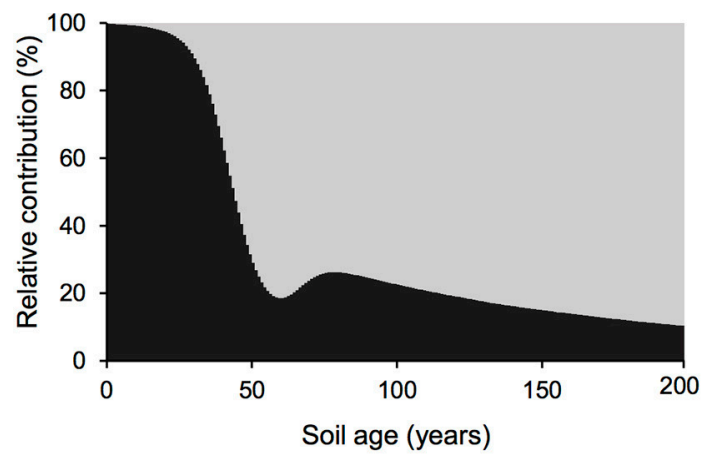

- Allochthonous deposition

Remineralized

FIGURE 5 | DIP budget. Relative contribution of allochthonous deposition (black) and remineralisation of organic matter (gray) to the DIP pool over 200 years of soil development for (A) BASE, (B) TEMP (RCP 8.5), (C) TEMPandSNOW (RCP 8.5), (D) NITRO (4.0), (E) SUBS (4.0), and (F) COMB (4.0).

\section{Response to Increased Nutrient and Organic Carbon Inputs (NITRO and SUBS)}

Model results show that microbial growth responded more strongly to increases in allochthonous DIN (NITRO) and organic carbon input (SUBS) than climatological changes (TEMP and TEMP\&SNOW), particularly in the very early stages of soil development (0-50 years) (Figure 6). DIN deposition exerted a greater effect on the non-nitrogen-fixing functional groups $\left(\mathrm{A}_{1}, \mathrm{~A}_{2}, \mathrm{H}_{1}, \mathrm{H}_{2}\right)$ reducing the pressure of DIN-limitation in young (0-50 year old) soils. Increased substrate input supported higher heterotrophic $\left(\mathrm{H}_{1-3}\right)$ (up to $111 \%$ ) and to a lesser extent autotrophic $\left(\mathrm{A}_{1-3}\right)$ (up to 68\%) biomass. Interestingly, the increased carbon inputs (SUBS) also caused long term increases in microbial biomass beyond the exponential growth phase, due to the enhanced supply of labile substrate to the older soils (100-200 years), which were typically depleted in labile organic matter. However, simulation results show that increased organic carbon and nutrient inputs did not trigger fundamental shifts in system behavior over the explored range. Total (autotrophic and heterotrophic) biomass responded linearly to increases 

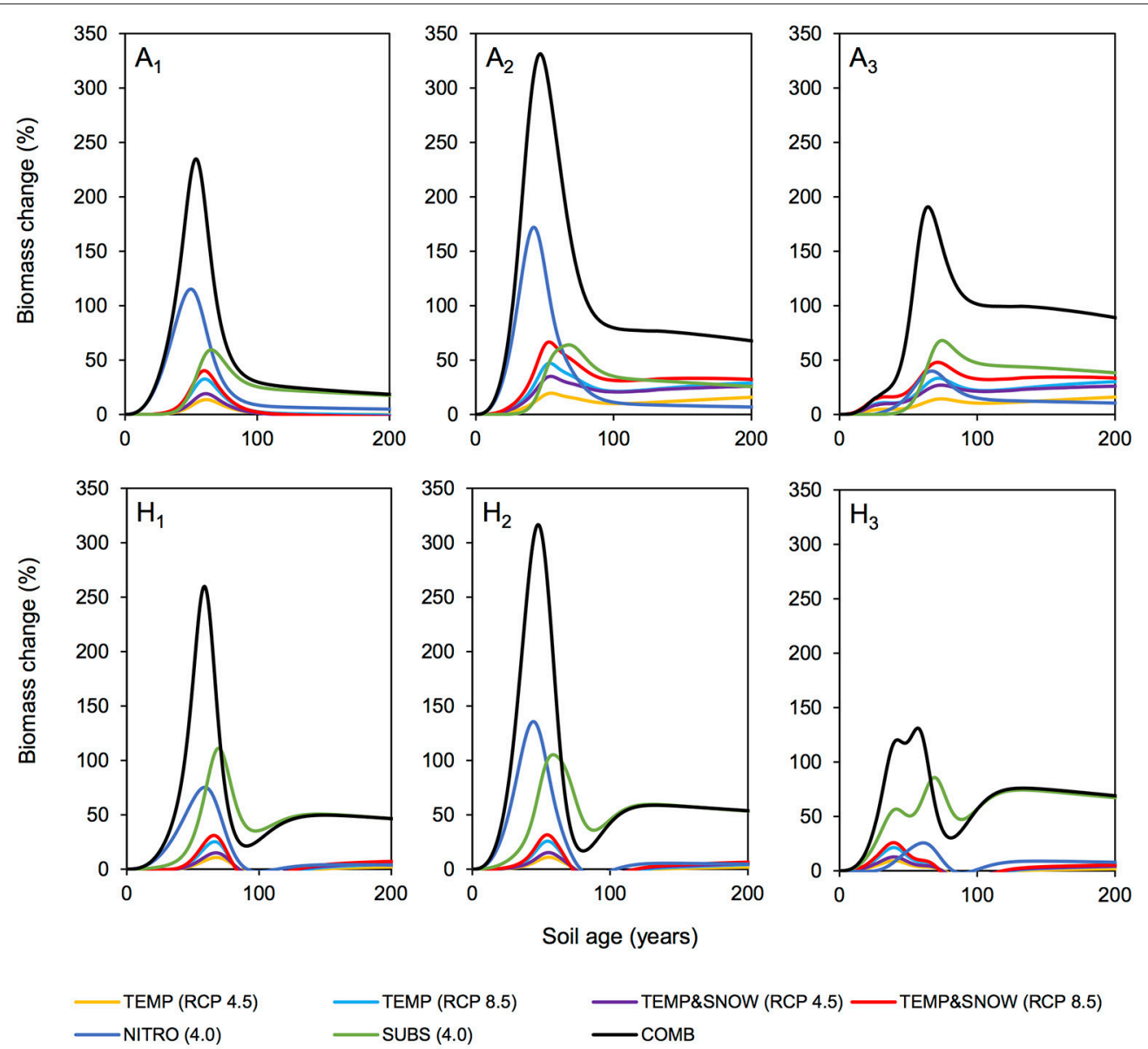

FIGURE 6 | Biomass response to climatological forcings. Percentage change in microbial biomass (relative to nominal (BASE) simulation) for individual microbial functional groups over 200 years of soil development. Simulations: TEMP (RCP 4.5) (yellow), TEMP (RCP 8.5) (light blue), TEMPandSNOW (RCP 4.5) (purple), TEMPandSNOW (RCP 8.5) (red), NITRO (4.0) (dark blue), SUBS (4.0) (green), and COMB (black).

in DIN and organic carbon input (Figure S1, Supplementary Information) and did not reveal tipping points, in contrast to studies on soils in temperate and desert regions (Zhou et al., 2012; Shcherbak et al., 2014; Scheer et al., 2016).

\section{Response to Combined Changes (COMB)}

In $\mathrm{COMB}$ we demonstrated that the combined effect of warming, snowmelt, and increased nitrogen and substrate input resulted in the largest increase in total microbial biomass (up to 190\% relative to baseline forcings) throughout two centuries of soil development compared to the effects of individual environmental variations considered independently. Furthermore, the observed peak response in biomass (Figure 6) occurred earlier than other scenarios. Bacteria were rapidly alleviated of growth-limitations by the additional organic substrate and nutrients. Thus, the bacterial communities could respond quicker and more strongly to more favorable thermal and light conditions as a result of climate warming. Similarly, initial warming enabled soil microbial communities to take advantage of favorable nutrient and substrate concentrations.

\section{Effect of Climate Change on Nutrient Dynamics in the Midtre Lovénbreen Forefield}

Accumulating nutrients can be derived from allochthonous sources, nitrogen fixation (for DIN) or the release of nutrients by heterotrophic decomposition of organic matter. The deposition of reactive nitrogen in snow is a major source of nitrogen in Arctic regions (Hodson et al., 2005, 2010; Kuhnel et al., 2011; Bjorkman et al., 2013). In addition, many studies on microbial dynamics in glacier forefields also draw attention to microbiallymediated nitrogen fixation as an important source of nitrogen to glacier forefield soils (Deiglmayr et al., 2006; Duc et al., 2009a,b; Brankatschk et al., 2011; Strauss et al., 2012; Ansari et al., 2013). Figure 7 illustrates the change in soil DIN (A) and DIP (B) stocks over 200 years of soil development for BASE, TEMP (RCP 8.5), TEMP\&SNOW (RCP 8.5), NITRO (4.0), SUBS (4.0), and COMB. Additionally, Figures 4, 5 show the relative contributions to soil DIN and DIP from allochthonous sources and organic carbon remineralisation, thus enabling separation of these two factors commonly observed only as a net outcome. 

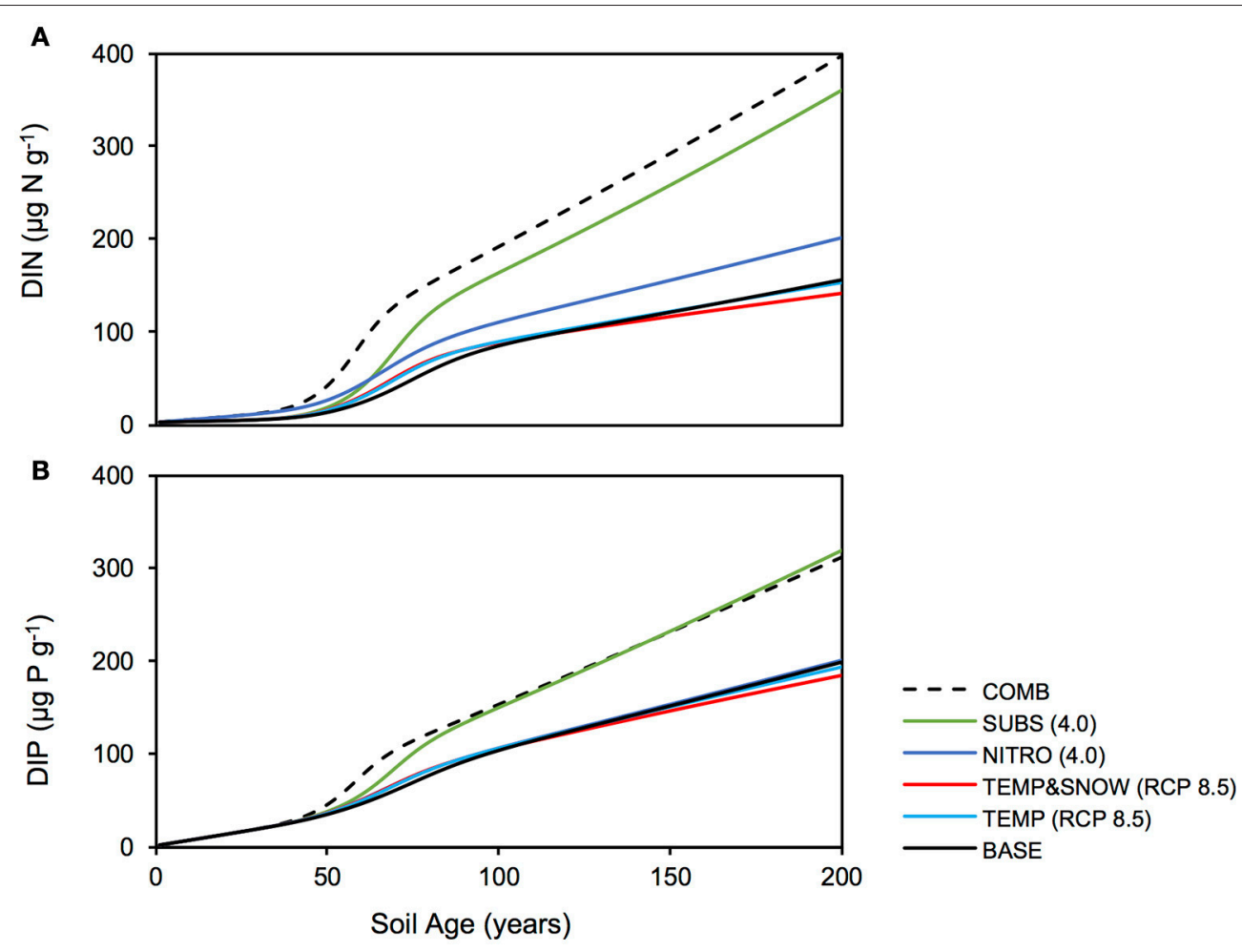

FIGURE 7 | Soil DIN and DIP response to climatological forcings. Response of soil (A) DIN and (B) DIP stocks to climatological forcings simulated in: BASE (solid black), TEMP (RCP 8.5) (light blue), TEMPandSNOW (RCP 8.5) (red), NITRO (4.0) (dark blue), SUBS (4.0) (green), and COMB (dashed black).

\section{General Response}

In all simulations, DIN and DIP accumulated from trace concentrations $\left(<4 \mu \mathrm{g} \mathrm{g}^{-1}\right)$ to $>150 \mu \mathrm{g} \mathrm{g}^{-1}$ over two centuries of soil development. In general, DIN and DIP fluxes were affected by all climate scenarios, but in particular, the greatest response was to organic carbon deposition, and the combination of all future changes (Figure 7). All climatological scenarios enhanced nutrient release by heterotrophic remineralisation of organic carbon. In TEMP and TEMP\&SNOW, however, nutrient uptake was also enhanced, causing a minor depletion of nutrients relative to BASE, whereas in NITRO, SUBS, and COMB, enhanced organic matter remineralisation caused net accumulation of DIN and DIP. Based on the predicted growth of nitrogenfixing autotrophs $\left(\mathrm{A}_{3}\right)$ and heterotrophs $\left(\mathrm{H}_{3}\right)$, modeling results suggest that nitrogen fixation contributed up to $0.03 \mu \mathrm{g} \mathrm{N} \mathrm{g}{ }^{-1}$ $\mathrm{y}^{-1}$ in intermediate and older soils (years 80-200). Nitrogen derived from nitrogen fixation is incorporated directly into biomass rather than soil DIN, however total nitrogen derived from nitrogen fixation would amount to only $2-4 \%$ of that from remineralisation. The effect of climatic and anthropogenic forcings explored in all future climate scenarios on the total nitrogen fixation was negligible (data not shown).

\section{Response to Increased Temperature and Decreased Snow Cover (TEMP and TEMP\&SNOW)}

Model results show that the contribution of organic carbon remineralisation to soil DIN and DIP increased in response to increased thermal and light conditions (TEMP and
TEMP\&SNOW) (Figures 4, 5). Heterotrophy is crucial to nutrient dynamics in glacier forefields, due to its role in the degradation of organic carbon into inorganic nutrients (Ingham et al., 1985). Under nominal conditions (BASE), DIN and DIP budgets were dominated by remineralisation rather than allochthonous deposition ( $>50 \%$ contribution) after 40 and 68 years of exposure respectively (see Figures $4 \mathbf{A}, \mathbf{5 A}$ ). In response to warming and earlier snowmelt (TEMP and TEMP\&SNOW, RCP 8.5), the $>50 \%$ threshold was reached 4 to 7 years earlier. Despite increased nutrient remineralisation, total nutrient stocks declined relative to BASE (Figure 7) due to enhanced bacterial growth. This is illustrated in Figure 6 whereby climatological changes caused more favorable growth conditions which enhanced bacterial production (Figure 6). Thus, although organic carbon degradation and nutrient cycling was enhanced, the growth of biomass was, overall, the dominant control on nutrient budgets.

\section{Response to Nutrient and Organic Carbon Inputs (NITRO and SUBS)}

Model results show that increased allochthonous DIN deposition caused total soil DIN to increase (Figure 7). Predictably, the prescribed increased in external DIN in NITRO caused an increase in the proportion of DIN derived from allochthonous sources (black, Figure 4D) throughout the entire simulation, by $\sim 1-15 \%$ compared to BASE. Further, the increased DIN deposition exerted a negligible effect on DIP budgets (Figure 5D), since the impact of DIN deposition on TOC 
decomposition, and thus DIP from remineralisation, was minimal (maximum relative change of $-2 \%$ ).

Model results show that the future delivery of allochthonous organic carbon to forefield soils may exert an important control on soil nutrient dynamics. Additional substrate [SUBS (4.0)] had the most pronounced effect on soil DIN and DIP stocks (Figure 7) for any single climatological forcing prescribed to the model, causing a maximum increase of $131 \%$ and $61 \%$ (respectively) relative to baseline forcings (BASE). Enhanced heterotrophic remineralisation of organic carbon substantially increased the relative contribution of nutrients derived from remineralisation (indicated in gray) to both the DIN pool (Figure 4E) and the DIP pool (Figure 5E). Consequently, this further stimulated the growth of all microbial groups $\left(\mathrm{A}_{1-3}\right.$ and $\mathrm{H}_{1-3}$ ) (green line, Figure 6). The abundance and bioavailability of phosphorus in glacier forefield soils has been causally linked to mineralogy, and particularly weathering of mineral surfaces (Anderson et al., 1997, 2000; Sattin et al., 2009; Prietzel et al., 2013). Here, we show through modeling, that the heterotrophic degradation of organic matter represents a major, potentially under-appreciated, process for sustaining sources of available nutrients to microbial communities in glacier forefield soils, particularly if organic carbon input to Arctic glacier forefields is enhanced in the future. The clear response of microbial growth to enhanced DIN and organic substrate deposition (NITRO and SUBS, Figure 6) is generally in line with the current perception of glacier forefields as nutrient-starved environments, and reinforces our result that nutrient availability is a major limiting factor on rates of bacterial growth and production (Jonsdottir et al., 1995; Duc et al., 2009b; Brankatschk et al., 2011; Schulz et al., 2013; Bradley et al., 2014).

\section{Response to Combined Changes (COMB)}

Model results suggested that when all climatological forcings were combined, total DIN and DIP stocks increased (Figure 7) and the contribution of remineralisation to DIN and DIP were elevated in comparison to the baseline forcings (Figures $4 \mathrm{~F}$, $5 F$ ). Despite the direct addition of DIN to soils from the COMB scenario, the effect of enhanced DIN delivery from remineralisation outweighed allochthonous DIN input. Warmer soils and increased exposure to PAR created more favorable conditions for bacterial growth. With strong allochthonous deposition of DIN and organic carbon, the limitations on microbial growth imposed by the availability of nutrients and labile substrate were alleviated in younger soils, and thus bacterial communities were able to respond more rapidly to the favorable thermal and light conditions created by climate change. Thus, heterotrophs grew rapidly (Figure 6) and nutrients were liberated from organic carbon at a much greater rate (Figures $4 \mathrm{~F}, 5 \mathrm{~F}$ ) causing their net accumulation in soils (Figure 7).

\section{Effect of Climatic Change on Carbon Dynamics and Net Ecosystem Production (NEP) in the Midtre Lovénbreen Forefield}

Figure 8 summarizes the response of the total soil TOC pool $\left(\mathrm{S}_{1}+\mathrm{S}_{2}\right)$ to the BASE, TEMP (RCP 2.5 and 8.5), TEMP\&SNOW (RCP 2.5 and 8.5 ), NITRO (1.2 to 4.0 ), SUBS (1.2 to 4.0 ) and
COMB scenarios. In addition, the seasonal evolution of dailyintegrated TOC production and consumption processes over year 200 is also shown in Figure 9 for the above-mentioned climate change scenarios to illustrate the variability of process rates. Net ecosystem production over 200 years of exposure is provided in Table 2.

\section{General Response}

Microbial dynamics exert an important control on carbon cycling and soil TOC content in glacier forefields (Guelland et al., 2013a,b; Schulz et al., 2013). Overall, the simulated response of glacier forefield soils to future climate change scenarios reinforce these observations. In contrast to the responses of soil nitrogen and phosphorous stocks, the responses of TOC stocks to the five climate and anthropogenic change scenarios were qualitatively and quantitatively different. Nitrogen deposition exerted a minimal effect on forefield TOC stocks, while climate change (TEMP and TEMP\&SNOW) and, in particular, organic carbon deposition and the combined scenario (COMB) triggered a more pronounced response (Figure 8). As discussed earlier, forefield organic carbon dynamics are controlled by the balance between organic carbon inputs by microbial necromass, as well as allochthonous sources, and the consumption of organic carbon by heterotrophic degradation and respiration. Simulation results show that rates of organic carbon consumption and production were characterized by a strong seasonal variability, with higher process rates in summer and lower rates during the winter months (Figure 9) resulting in a net accumulation of TOC during summer (May-October) and a consumption of TOC stocks during the rest of the year in all scenarios. The relative significance of organic carbon inputs through necromass (light blue line, Figure 9) or allochthonous material (yellow line, Figure 9) was roughly equal in BASE and NITRO (4.0). However, in TEMP (RCP 8.5), TEMP\&SNOW (RCP 8.5) and $\mathrm{COMB}$, organic carbon inputs were dominated by necromass, while organic carbon inputs were dominated by external (allochthonous) deposition in the SUBS (4.0) scenario. Yet, the forefield soil was net heterotrophic (NEP $<0$; heterotrophic respiration $>$ autotrophic fixation) for all scenarios during all stages of soil development (Table 2), thus, emphasizing the importance of allochthonous organic carbon inputs on forefield ecosystem dynamics.

\section{Response to Increased Temperature and Decreased Snow Cover (TEMP and TEMP\&SNOW)}

Heterotrophic respiration and growth rates, as well as the input of necromass, increased by a factor of eight in response to the temperature increase (TEMP RCP 8.5, Figure 9B). In addition, the earlier snowmelt allowed an earlier onset of microbial activity (mid-April compared to mid-June) (TEMP\&SNOW RCP 8.5, Figure 9C). Simulation results indicate that soil warming and earlier onset of spring snow melt (TEMP and TEMP\&SNOW) initially resulted in a slight depletion of soil organic carbon (relative to BASE) (Figure 8A), due to the increased consumption of labile substrate by enhanced heterotrophic degradation rates. However, on long time scales ( $>100$ years), enhanced autotrophic growth and the associated increase in necromass (Figures 9B,C) 

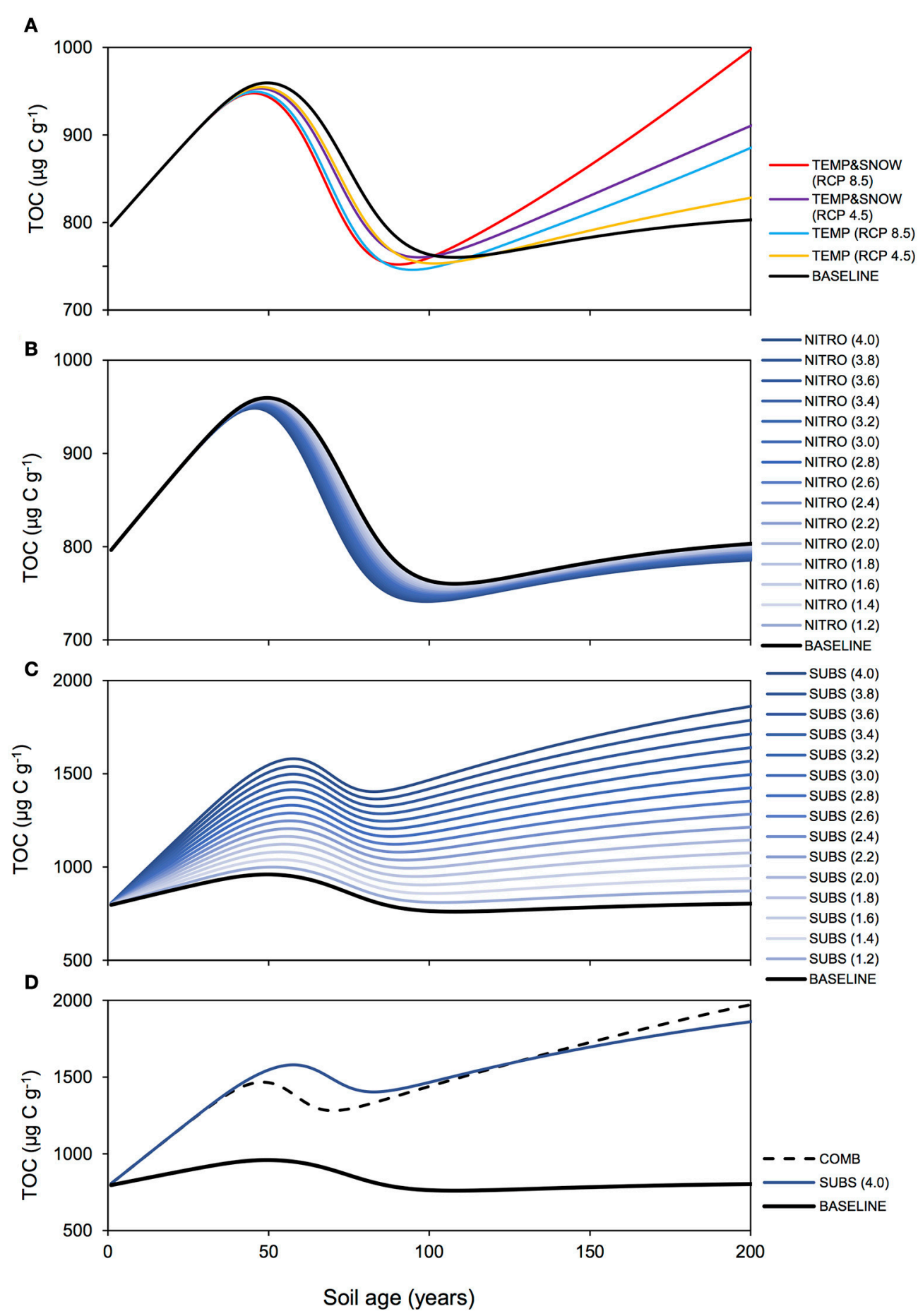

FIGURE 8 | TOC response to climatological forcings. Modeled total organic carbon (TOC) over 200 years for (A) BASE, TEMP, and TEMPandSNOW, (B) NITRO (1.2-4.0), (C) SUBS (1.2-4.0), and (D) COMB.

supported the accumulation of refractory organic carbon in the forefield (Figure 9A). In the most extreme warming and snowmelt scenarios, the long-term accumulation of refractory organic carbon resulted in a $24 \%$ increase in soil TOC compared to baseline values (red line, Figure 8). Enhanced autotrophic growth (Figure 6) also increased NEP by $10.3 \%$ and $24.0 \%$ for TEMP (RCP 8.5) and TEMP\&SNOW (RCP 8.5) respectively (Table 2). The positive response of autotrophic growth to warming thus theoretically renders a negative feedback possible, whereby $\mathrm{CO}_{2}$-induced Arctic warming and snowmelt over large 

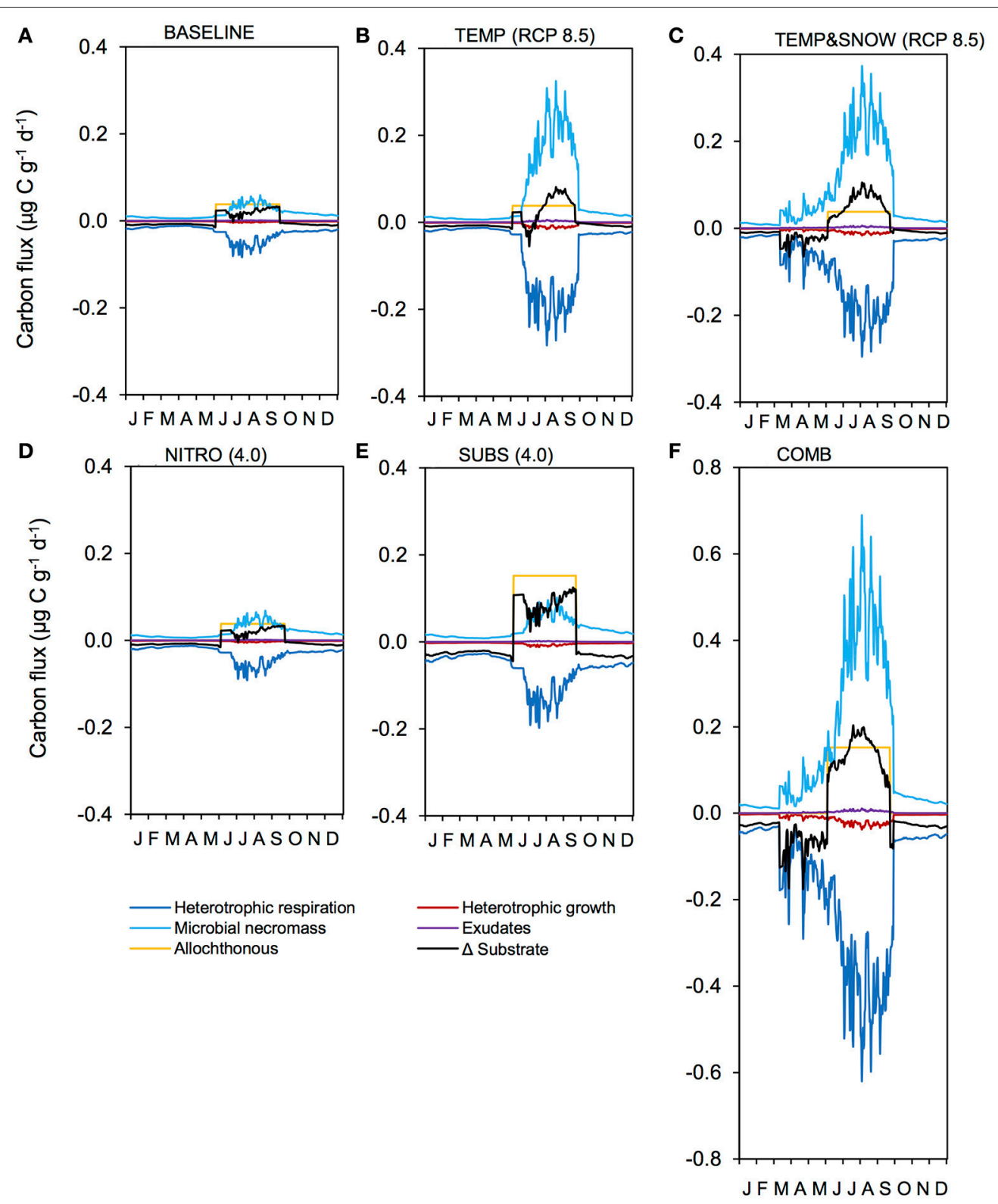

FIGURE 9 | Carbon fluxes in response to climatological forcings. Illustration of daily carbon fluxes in soil after 200 years of development, for simulations: (A) BASE, (B) TEMP (RCP 8.5), (C) TEMPandSNOW (RCP 8.5), (D) NITRO (4.0), (E) SUBS (4.0), and (F) COMB. Microbial necromass (light blue), exudates (purple) and allochthonous sources (yellow) contribute to the substrate pool (black), and heterotrophic growth (dark red) and respiration (dark blue) deplete it.

areas could enhance $\mathrm{CO}_{2}$ fixation from the atmosphere by autotrophic activity. Simulation results suggest that this effect may be sustained in the later stages of soil development where biomass is greater, and where plants may become established. However, even under the extreme warming scenario simulated here the forefield remained net heterotrophic $(\mathrm{NEP}<0)$.

\section{Response to Nutrient and Organic Carbon Inputs (NITRO and SUBS)}

Enhanced deposition of DIN (NITRO) alleviated nutrient limitation, resulting in a depletion of TOC relative to the baseline scenario (years 50-200), due to the enhanced degradation of labile organic matter by heterotrophic activity (Figure 6). In general, however, the impact of enhanced DIN deposition on soil TOC dynamics was minimal, and resulted in relative reduction of $-2 \%$ in TOC stocks (from 4 times DIN deposition) (Figure 8B). Moreover, the most extreme DIN deposition scenario [NITRO (4.0)] simultaneously enhanced both autotrophy $\left(\mathrm{CO}_{2}\right.$ fixation) and heterotrophy $\left(\mathrm{CO}_{2}\right.$ production), and thus exerted a negligible effect on NEP over 200 years (-2\%) compared to other climate change scenarios (TEMP, TEMP\&SNOW, and SUBS). 
TABLE 2 | Net ecosystem production over 200 years of exposure.

\begin{tabular}{lc}
\hline Simulation & Net ecosystem production $\left(\boldsymbol{\mu} \mathbf{g} \mathbf{~} \mathbf{~ g}^{\mathbf{- 1}}\right)$ \\
\hline BASE & -823 \\
TEMP (RCP 4.5) & -797 \\
TEMP (RCP 8.5) & -739 \\
TEMP\&SNOW (RCP 4.5) & -719 \\
TEMP\&SNOW (RCP 8.5) & -626 \\
NITRO (4.0) & -842 \\
SUBS (4.0) & -2310 \\
COMB & -2195 \\
\hline
\end{tabular}

Conversely, allochthonous inputs of organic carbon were an important factor in sustaining microbial growth in newly exposed glacier forefields by exerting a strong influence on forefield TOC stocks (Figure 8C). By integrating daily carbon fluxes over the 200-year simulation period, model predictions suggest that under extreme substrate input fluxes [SUBS (4.0)], allochthonous deposition contributed roughly 3 times more organic carbon (3.34 $\mathrm{mg} \mathrm{C} \mathrm{g}^{-1}$ ) than microbial necromass $\left(1.08 \mathrm{mg} \mathrm{C} \mathrm{g}^{-1}\right.$ ).

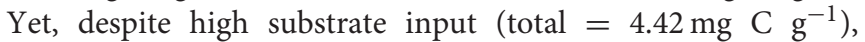

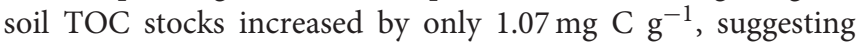
that most of the organic substrate delivered to the TOC pool $(>75 \%)$ was rapidly utilized by heterotrophic activity. This caused a considerable decrease to NEP relative to the BASE scenario ( $-180.5 \%$, Table 2). Overall, these findings reinforce previous experimental evidence suggesting that labile organic carbon is a limiting factor on bacterial activity in established glacier forefield soils (Goransson et al., 2011; Bradley et al., 2016b). Therefore, accurately predicting the likely magnitude of future organic carbon input to Arctic glacier forefields deserves attention.

\section{Response to Combined Changes (COMB)}

TOC accumulation in COMB mirrored high rates of TOC accumulation in SUBS (4.0) until the rapid growth phase (Figure 8D), upon which more favorable temperature and nutrient conditions enabled enhanced heterotrophic degradation, and TOC stocks declined moderately. The simulated carbon fluxes driven by COMB closely resembled TEMP\&SNOW (RCP 8.5) (i.e., the period of increased microbial activity was extended earlier into the spring), but the overall magnitude of fluxes were substantially larger (Figure 9F). This resulted from increased biological activity due to the increased availability of organic carbon, aligning with the higher microbial abundance discussed earlier. Increased delivery of necromass contributed to the soil TOC pool (Figure 9F). Favorable conditions for phototrophic growth caused fixation of $\mathrm{CO}_{2}$ such that total NEP for COMB $\left(-2195 \mu \mathrm{g} \mathrm{C} \mathrm{g}^{-1}\right)$ was higher than when considering deposition of organic carbon [SUBS (4.0)] alone (-2310 $\mu \mathrm{g} \mathrm{C} \mathrm{g}^{-1}$ ) (Table 2). Overall, NEP was still substantially lower than the BASE simulation $\left(-823 \mu \mathrm{g} \mathrm{C}^{-1}\right)$, emphasizing the potential susceptibility of soil-atmosphere $\mathrm{CO}_{2}$ exchange to future climate change (Billings, 1987; Oechel et al., 1993, 2000; Goulden et al., 1998).

\section{CONCLUSIONS AND OUTLOOK}

Arctic ecosystems are generally adapted to low availability of nutrients and relatively extreme changes in climate (Jonsdottir et al., 1995; Jonsdottir, 2005). We have shown that the anthropogenically driven emission of pollutants (including reactive nitrogen) and greenhouse gasses and its cascading effects on the Arctic environment (such as increases in soil temperature, the length of the melting season, and the availability of carbon and nutrients), has the potential to considerably impact the functioning of a basic soil microbial community in the initial stages of soil development in the present day and for centuries into the future. This is important in the context of increased glacier retreat and soil formation over large expanses of presently ice-covered regions. Our results thus demonstrate that future attempts to characterize soil development in glacier forefields must also consider changes to environmental, climatic and anthropogenic drivers. We have made important initial approximations of the sensitivity of microbiological and biogeochemical processes in forefield soils to future climate change by addressing the simulated responses to changes in temperature, snow cover and nutrient input. However, these initial approximations require further testing with in situ fieldbased experiments. The results of ecological models critically depend on the model used (Jackson et al., 2000; Meile and Jones, 2016). Although, SHIMMER has been carefully calibrated and tested based on field data from the Midtre Lovénbreen forefield (Bradley et al., 2016b) and thus is the most appropriate tool for the present study, further empirical measurements and experiments simulating soil warming and nutrient deposition may validate these predictions and strengthen the conclusions drawn here.

Critically, future studies must identify the role of nutrient availability on fungi and plant colonization (Insam and Haselwandter, 1989; Bernasconi et al., 2011; Knelman et al., 2012; Zumsteg et al., 2012; Schulz et al., 2013; Brown and Jumpponen, 2014). The SHIMMER model does not include a vegetation component and is thus not able to account for the effect of plants (Bradley et al., 2015). Whereas Alpine glacier forefields are usually abundant with vascular vegetation soon after ice retreat (Miniaci et al., 2007; Bernasconi et al., 2011), the initial young stages of the Midtre Lovénbreen forefield soils are characterized by almost a complete absence of plants. The Midtre Lovénbreen forefield is thus an ideal system to study the interactions between microbes and rock during soil formation. This forefield is also representative of a major Polar ecosystem, since most of the non-ice-covered surface land area of Antarctica and the high Arctic have very little plant coverage (Vanderpuye et al., 2002; Okuda et al., 2007, 2011; Birks, 2008). Plant colonization is likely to heavily re-structure the microbial community (Brown and Jumpponen, 2014), and the physical properties of the soil, including water retention, ultraviolet exposure, temperature fluctuations (Ensign et al., 2006; King et al., 2008) and nutrient status (Kastovska et al., 2005; Schutte et al., 2009). For example, Duc et al. (2009b) compared rhizosphere and bulk soils in the Damma Glacier, and found substantially higher 
total organic carbon concentrations in soils sampled in close proximity to plants. Thus, if plants were to become established within the simulated period, the results may be somewhat different. Although, the forcings investigated in the model caused increasing efflux of $\mathrm{CO}_{2}$, the accelerated remineralisation and release of nutrients created favorable conditions for plants, which may encourage growth (Insam and Haselwandter, 1989; Bernasconi et al., 2011; Brown and Jumpponen, 2014). Plants may then cause a reduction in net soil $\mathrm{CO}_{2}$ efflux by enhancing primary productivity (D'Amico et al., 2014), but may also generate more litter to fuel heterotrophy (Guelland et al., 2013a).

Our model analyses robustly indicate that microbial activity, nutrient cycling, and carbon cycling in the Midtre Lovénbreen forefield can respond strongly to future climate and anthropogenic impacts. Our simulations suggest that:

- Climate and anthropogenic changes generally enhance bacterial production and increase soil carbon and nutrient stocks. The strength of this response is highly variable between simulations.

- Nutrient availability is a major limiting factor for microbial activity in recently exposed soils and thus exerts a major control on the ability of forefield microbial communities to respond to climate change.

- Pioneer communities are most susceptible to climatological changes.

- Microbial and thus biogeochemical dynamics are mainly controlled by allochthonous nutrient inputs in younger soils. In developed soils, the heterotrophic recycling of allochthonous organic carbon and, to a lesser extent, necromass, causes sufficient nutrient accumulation over the course of a century of soil development to alleviate the dependence on allochthonous nutrient inputs.

- Climatological forcings encourage a more rapid switch between allochthonously-dominated processes in young soils to microbially-dominated processes in older soils.

- Factors that enhance heterotrophic activity, such as favorable temperatures and increased organic substrate, contribute additional nutrients via remineralization, which may facilitate earlier colonization by fungi and plants.

- The Midtre Lovénbreen forefield is net heterotrophic (NEP < 0 ) for the length of the simulated period and all climate change

\section{REFERENCES}

Anderson, S. P., Drever, J. I., Frost, C. D., and Holden, P. (2000). Chemical weathering in the foreland of a retreating glacier. Geochim. Cosmochim. Acta 64, 1173-1189. doi: 10.1016/S0016-7037(99)00358-0

Anderson, S. P., Drever, J. I., and Humphrey, N. F. (1997). Chemical weathering in glacial environments. Geology 25, 399-402. doi: 10.1130/0091-7613(1997) 025<0399:CWIGE > 2.3.CO;2

Anesio, A. M., and Laybourn-Parry, J. (2012). Glaciers and ice sheets as a biome. Trends Ecol. Evol. 27, 219-225. doi: 10.1016/j.tree.2011.09.012

Anisimov, O. A., Vaughan, D. G., Callaghan, T. V., Furgal, C., Marchant, H., Prowse, T. D., et al. (2007). "Polar regions (Arctic and Antarctic)," in Climate Change 2007: Impacts, Adaptation and Vulnerability, eds O. F. Canziani, J. P. scenarios. However, warming and reduced snow cover lower the net heterotrophy, while the increase in allochthonous inputs generally increase net heterotrophy.

- The Midtre Lovénbreen forefield is resilient to tipping points, in that, even with a combination of the most extreme climatological and anthropogenic changes, soil microbiology and biogeochemistry responded with an amplification of the baseline dynamics, rather than major fundamental shifts.

\section{AUTHOR CONTRIBUTIONS}

JB led the design of the study, assisted by AA and SA. The simulations were conducted by JB. All authors interpreted model results. JB wrote the manuscript with contributions from AA and SA.

\section{FUNDING}

This work was supported by Natural Environment Research Council (grant number NE/J02399X/1 to AA). JB was partially supported by a Postdoctoral Fellowship from the National Science Foundation Center for Dark Energy Biosphere Investigations (OCE-0939564). SA received funding from the European Union's Horizon 2020 research and innovation program under the Marie Sklodowska-Curie grant agreement number 643052 (C-CASCADES). This is the Center for Dark Energy Biosphere Investigations (C-DEBI) publication 363.

\section{ACKNOWLEDGMENTS}

We would like to thank the two reviewers who provided valuable comments on the manuscript.

\section{SUPPLEMENTARY MATERIAL}

The Supplementary Material for this article can be found online at: http://journal.frontiersin.org/article/10.3389/feart. 2017.00026/full\#supplementary-material

Figure S1 | Biomass response to deposition scenarios. Additional biomass resulting from (A) increased nitrogen deposition (NITRO) and (B) increased substrate deposition (SUBS) over 200 years of soil development. Inset: additional biomass in (A) year 50 and (B) year 200 with increased DIN and substrate input.

Ansari, A. H., Hodson, A. J., Heaton, T. H. E., Kaiser, J., and Marca-Bell, A. (2013). Stable isotopic evidence for nitrification and denitrification in a High Arctic glacial ecosystem. Biogeochemistry 113, 341-357. doi: 10.1007/s10533-012-9761-9

Bernasconi, S. M., Bauder, A., Bourdon, B., Brunner, I., Bunemann, E., Christl, I., et al. (2011). Chemical and biological gradients along the damma glacier soil chronosequence, Switzerland. Vadose Zo. J. 10, 867-883. doi: $10.2136 /$ vzj2010.0129

Billings, W. D. (1987). Carbon balance of alaskan tundra and taiga ecosystems - past, present and future. Quat. Sci. Rev. 6, 165-177. doi: 10.1016/0277-3791(87)90032-1 
Birks, H. H. (2008). The late-quaternary history of arctic and alpine plants. Plant Ecol. Divers. 1, 135-146. doi: 10.1080/17550870802328652

Birks, H. J. B., Jones, V. J., and Rose, N. L. (2004). Recent environmental change and atmospheric contamination on Svalbard as recorded in lake sediments - synthesis and general conclusions. J. Paleolimnol. 31, 531-546. doi: 10.1023/B:JOPL.0000022550.81129.1a

Bjorkman, M. P., Kuhnel, R., Partridge, D. G., Roberts, T. J., Aas, W., Mazzola, M., et al. (2013). Nitrate dry deposition in Svalbard. Tellus Ser. B. Chem. Phys. Meteorol. 65:19071. doi: 10.3402/tellusb.v65i0.19071

Bradley, J. A., Anesio, A., and Arndt, S. (2016a). Bridging the divide: a model-data approach to Polar \& Alpine microbiology. FEMS Microbiol. Ecol. 92:fiw015. doi: 10.1093/femsec/fiw015

Bradley, J. A., Anesio, A. M., Singarayer, J. S., Heath, M. R., and Arndt, S. (2015). SHIMMER (1.0): a novel mathematical model for microbial and biogeochemical dynamics in glacier forefield ecosystems. Geosci. Model Dev. 8, 3441-3470. doi: 10.5194/gmd-8-3441-2015

Bradley, J. A., Arndt, S., Šabacká, M., Benning, L. G., Barker, G. L., Blacker, J. J., et al. (2016b). Microbial dynamics in a High Arctic glacier forefield: a combined field, laboratory, and modelling approach. Biogeosciences 13, 5677-5696. doi: 10.5194/bg-13-5677-2016

Bradley, J. A., Singarayer, J. S., and Anesio, A. M. (2014). Microbial community dynamics in the forefield of glaciers. Proc. Biol. Sci. 281, 2793-2802. doi: 10.1098/rspb.2014.0882

Brankatschk, R., Towe, S., Kleineidam, K., Schloter, M., and Zeyer, J. (2011). Abundances and potential activities of nitrogen cycling microbial communities along a chronosequence of a glacier forefield. ISME J. 5, 1025-1037. doi: 10.1038/ismej.2010.184

Brown, S. P., and Jumpponen, A. (2014). Contrasting primary successional trajectories of fungi and bacteria in retreating glacier soils. Mol. Ecol. 23, 481-497. doi: $10.1111 / \mathrm{mec} .12487$

Callaghan, T. V., Press, M. C., Lee, J. A., Robinson, D. L., and Anderson, C. W. (1999). Spatial and temporal variability in the responses of Arctic terrestrial ecosystems to environmental change. Polar Res. 18, 191-197. doi: 10.3402/polar.v18i2.6574

Ciais, P., Sabine, C., Bala, G., Bopp, L., Brovkin, V., Canadell, J., et al. (2013). "Carbon and other biogeochemical cycles," in Climate Change 2013: The Physical Science Basis. Contribution of Working Group I to the Fifth Assessment Report of the Intergovernmental Panel on Climate Change, eds T. F. Stocker, D. Qin, G. Plattner, M. Tignor, S. Allen, J. Boschung, A. Nauels, Y. Xia, V. Bex, and P. Midgley (Cambridge; New York, NY: Cambridge University Press), 465-570.

D'Amico, M. E., Freppaz, M., Filippa, G., and Zanini, E. (2014). Vegetation influence on soil formation rate in a proglacial chronosequence (Lys Glacier, NW Italian Alps). Catena 113, 122-137. doi: 10.1016/j.catena.2013.10.001

Deiglmayr, K., Philippot, L., Tscherko, D., and Kandeler, E. (2006). Microbial succession of nitrate-reducing bacteria in the rhizosphere of Poa alpina across a glacier foreland in the Central Alps. Environ. Microbiol. 8, 1600-1612. doi: 10.1111/j.1462-2920.2006.01051.x

Duc, L., Neuenschwander, S., Rehrauer, H., Wagner, U., Sobek, J., Schlapbach, R., et al. (2009a). Development and experimental validation of a nifH oligonucleotide microarray to study diazotrophic communities in a glacier forefield. Environ. Microbiol. 11, 2179-2189. doi: 10.1111/j.1462-2920.2009.01945.x

Duc, L., Noll, M., Meier, B. E., Burgmann, H., and Zeyer, J. (2009b). High diversity of diazotrophs in the forefield of a receding Alpine Glacier. Microb. Ecol. 57, 179-190. doi: 10.1007/s00248-008-9408-5

Eckhardt, S., Hermansen, O., Grythe, H., Fiebig, M., Stebel, K., Cassiani, M., et al. (2013). The influence of cruise ship emissions on air pollution in Svalbard a harbinger of a more polluted Arctic? Atmos. Chem. Phys. 13, 8401-8409. doi: 10.5194/acp-13-8401-2013

Eneroth, K., Kjellstrom, E., and Holmen, K. (2003). A trajectory climatology for Svalbard; investigating how atmospheric flow patterns influence observed tracer concentrations. Phys. Chem. Earth 28, 1191-1203. doi: 10.1016/j.pce.2003.08.051

Ensign, K. L., Webb, E. A., and Longstaffe, F. J. (2006). Microenvironmental and seasonal variations in soil water content of the unsaturated zone of a sand dune system at Pinery Provincial Park, Ontario, Canada. Geoderma 136, 788-802. doi: 10.1016/j.geoderma.2006.06.009
Fleming, K. M., Dowdeswell, J. A., and Oerlemans, J. (1997). Modelling the mass balance of northwest Spitsbergen glaciers and responses to climate change. Ann. Glaciol. 24, 203-210. doi: 10.1017/s02603055000 12180

Foreman, C. M., Sattler, B., Mikucki, J. A., Porazinska, D. L., and Priscu, J. C. (2007). Metabolic activity and diversity of cryoconites in the Taylor Valley, Antarctica. J. Geophys. Res. 112:G04S32. doi: 10.1029/2006jg000358

Forland, E. J., Benestad, R., Hanssen-Bauer, I., Haugen, J. E., and Skaugen, T. E. (2011). Temperature and Precipitation Development at Svalbard 1900-2100. Adv. Meteorol. 2011:893790. doi: 10.1155/2011/893790

Fountain, A. G., Nylen, T. H., Tranter, M., and Bagshaw, E. (2008). Temporal variations in physical and chemical features of cryoconite holes on Canada Glacier, McMurdo Dry Valleys, Antarctica. J. Geophys. Res. 113:G01S92. doi: 10.1029/2007jg000430

Fountain, A. G., Tranter, M., Nylen, T. H., Lewis, K. J., and Mueller, D. R. (2004). Evolution of cryoconite holes and their contribution to meltwater runoff from glaciers in the McMurdo Dry Valleys, Antarctica. J. Glaciol. 50, 35-45. doi: 10.3189/172756504781830312

Galloway, J. N., Townsend, A. R., Erisman, J. W., Bekunda, M., Cai, Z., Freney, J. R., et al. (2008). Transformation of the nitrogen cycle: recent trends, questions, and potential solutions. Science 320, 889-892. doi: 10.1126/science.1136674

Geng, L., Alexander, B., Cole-Dai, J., Steig, E. J., Savarino, J., Sofen, E. D., et al. (2014). Nitrogen isotopes in ice core nitrate linked to anthropogenic atmospheric acidity change. Proc. Natl. Acad. Sci. U.S.A. 111, 5808-5812. doi: 10.1073/pnas.1319441111

Goransson, H., Venterink, H. O., and Baath, E. (2011). Soil bacterial growth and nutrient limitation along a chronosequence from a glacier forefield. Soil Biol. Biochem. 43, 1333-1340. doi: 10.1016/j.soilbio.2011.03.006

Goto-Azuma, K., and Koerner, R. M. (2001). Ice core studies of anthropogenic sulfate and nitrate trends in the Arctic. J. Geophys. Res. 106, 4959-4969. doi: 10.1029/2000JD900635

Goulden, M. L., Wofsy, S. C., Harden, J. W., Trumbore, S. E., Crill, P. M., Gower, S. T., et al. (1998). Sensitivity of boreal forest carbon balance to soil thaw. Science 279, 214-217. doi: 10.1126/science.279.5348.214

Greenfell, T. C., and Maykut, G. A. (1977). The optical properties of ice and snow in the Arctic basin. J Glaciol. 18, 455-463. doi: 10.1017/S0022143000021122

Guelland, K., Esperschutz, J., Bornhauser, D., Bernasconi, S. M., Kretzschmar, R., and Hagedorn, F. (2013a). Mineralisation and leaching of C from C-13 labelled plant litter along an initial soil chronosequence of a glacier forefield. Soil Biol. Biochem. 57, 237-247. doi: 10.1016/j.soilbio.2012.07.002

Guelland, K., Hagedorn, F., Smittenberg, R. H., Goransson, H., Bernasconi, S. M., Hajdas, I., et al. (2013b). Evolution of carbon fluxes during initial soil formation along the forefield of Damma glacier, Switzerland. Biogeochemistry 113, 545-561. doi: 10.1007/s10533-012-9785-1

Hastings, M. G., Jarvis, J. C., and Steig, E. J. (2009). Anthropogenic impacts on nitrogen isotopes of Ice-Core nitrate. Science 324, 1288. doi: $10.1126 /$ science. 1170510

Hodson, A. J., Mumford, P. N., Kohler, J., and Wynn, P. M. (2005). The High Arctic glacial ecosystem: new insights from nutrient budgets. Biogeochemistry 72, 233-256. doi: 10.1007/s10533-004-0362-0

Hodson, A., Roberts, T. J., Engvall, A. C., Holmen, K., and Mumford, P. (2010). Glacier ecosystem response to episodic nitrogen enrichment in Svalbard, European High Arctic. Biogeochemistry 98, 171-184. doi: 10.1007/s10533-009-9384-y

Holland, E. A., Braswell, B. H., Lamarque, J. F., Townsend, A., Sulzman, J., Muller, J. F., et al. (1997). Variations in the predicted spatial distribution of atmospheric nitrogen deposition and their impact on carbon uptake by terrestrial ecosystems. J. Geophys. Res. 102, 15849-15866. doi: 10.1029/96JD03164

Hood, E., Battin, T. J., Fellman, J., O’Neel, S., and Spencer, R. G. M. (2015). Storage and release of organic carbon from glaciers and ice sheets. Nat. Geosci. 8, 91-96. doi: 10.1038/ngeo2331

Hood, E., and Berner, L. (2009). Effects of changing glacial coverage on the physical and biogeochemical properties of coastal streams in southeastern Alaska. J. Geophys. Res. 114:G03001. doi: 10.1029/2009jg000971

Ingham, R. E., Trofymow, J. A., Ingham, E. R., and Coleman, D. C. (1985). Interactions of bacteria, fungi, and their Nematode Grazers : effects on nutrient cycling and plant growth. Ecol. Monogr. 55, 119-140. doi: 10.2307/1942528 
Insam, H., and Haselwandter, K. (1989). Metabolic quotient of the soil microflora in relation to plant succession. Oecologia 79, 174-178. doi: 10.1007/BF00388474

Isaksson, E., Hermanson, M., Sheila, H. C., Igarashi, M., Kamiyama, K., Moore, J., et al. (2003). Ice cores from Svalbard - useful archives of past climate and pollution history. Phys. Chem. Earth 28, 1217-1228. doi: 10.1016/j.pce.2003.08.053

Jackson, L. J., Trebitz, A. S., and Cottingham, K. L. (2000). An introduction to the practice of ecological modeling. Bioscience 50, 694-706. doi: 10.1641/00063568(2000)050[0694:AITTPO]2.0.CO;2

Jonsdottir, I. S. (2005). Terrestrial ecosystems on Svalbard: heterogeneity, complexity and fragility from an Arctic island perspective. Biol. Environ. Proc. R. Irish Acad. 105B, 155-165. doi: 10.3318/BIOE.2005.105.3.155

Jonsdottir, I. S., Callaghan, T. V., and Lee, J. A. (1995). Fate of added nitrogen in a moss sedge arctic community and effects of increased nitrogen deposition. Sci. Total Environ. 160-61, 677-685. doi: 10.1016/0048-9697(95) 04402-M

Kastovska, K., Elster, J., Stibal, M., and Santruckova, H. (2005). Microbial assemblages in soil microbial succession after glacial retreat in Svalbard (high Arctic). Microb. Ecol. 50, 396-407. doi: 10.1007/s00248-005-0246-4

Kelly, B., Whiteley, A., and Tallmon, D. (2010). The Arctic melting pot. Nature 468:891. doi: 10.1038/468891a

King, A. J., Meyer, A. F., and Schmidt, S. K. (2008). High levels of microbial biomass and activity in unvegetated tropical and temperate alpine soils. Soil Biol. Biochem. 40, 2605-2610. doi: 10.1016/j.soilbio.2008.06.026

Kirchman, D. L., Moran, X. A. G., and Ducklow, H. (2009). Microbial growth in the polar oceans - role of temperature and potential impact of climate change. Nat. Rev. Microbiol. 7, 451-459. doi: 10.1038/nrmicro2115

Knelman, J. E., Legg, T. M., O’Neill, S. P., Washenberger, C. L., Gonzalez, A., Cleveland, C. C., et al. (2012). Bacterial community structure and function change in association with colonizer plants during early primary succession in a glacier forefield. Soil Biol. Biochem. 46, 172-180. doi: 10.1016/j.soilbio.2011.12.001

Kuhnel, R., Bjorkman, M. P., Vega, C. P., Hodson, A., Isaksson, E., and Strom, J. (2013). Reactive nitrogen and sulphate wet deposition at Zeppelin Station, Ny-Alesund, Svalbard. Polar Res. 32:19136. doi: 10.3402/polar.v32i0.19136

Kuhnel, R., Roberts, T. J., Bjorkman, M. P., Isaksson, E., Aas, W., Holmen, K., et al. (2011). 20-year climatology of $\mathrm{NO}_{3}^{-}$and $\mathrm{NH}_{4}^{+}$wet deposition at $\mathrm{Ny}$-Ålesund, Svalbard. Adv. Meteorol. 2011:406508. doi: 10.1155/2011/406508

Larose, C., Dommergue, A., and Vogel, T. M. (2013a). Microbial nitrogen cycling in Arctic snowpacks. Environ. Res. Lett. 8:035004. doi: 10.1088/1748-9326/8/3/035004

Larose, C., Dommergue, A., and Vogel, T. M. (2013b). The dynamic arctic snow pack: an unexplored environment for microbial diversity and activity. Biology 2, 317-330. doi: 10.3390/biology2010317

Lau, M. C. Y., Stackhouse, B. T., Layton, A. C., Chauhan, A., Vishnivetskaya, T. A., Chourey, K., et al. (2015). An active atmospheric methane sink in high Arctic mineral cryosols. ISME J. 9, 1880-1891. doi: 10.1038/ismej.2015.13

Lazzaro, A., Hilfiker, D., and Zeyer, J. (2015). Structures of microbial communities in Alpine soils: seasonal and elevational effects. Front. Microbiol. 6:1330. doi: $10.3389 /$ fmicb. 2015.01330

Lefauconnier, B., Hagen, J. O., Orbaek, J. B., Melvold, K., and Isaksson, E. (1999). Glacier balance trends in the Kongsfjorden area, western Spitsbergen, Svalbard, in relation to the climate. Polar Res. 18, 307-313. doi: 10.3402/polar.v18i2.6589

Lenton, T. M. (2012). Arctic climate tipping points. Ambio 41, 10-22. doi: $10.1007 / \mathrm{s} 13280-011-0221-\mathrm{x}$

Luoto, T. P., Oksman, M., and Ojala, A. E. K. (2015). Climate change and bird impact as drivers of High Arctic pond deterioration. Polar Biol. 38, 357-368. doi: 10.1007/s00300-014-1592-9

Lutz, S., Anesio, A. M., Edwards, A., and Benning, L. G. (2015). Microbial diversity on Icelandic glaciers and ice caps. Front. Microbiol. 6:307. doi: $10.3389 /$ fmicb. 2015.00307

Macdonald, R. W., Harner, T., and Fyfe, J. (2005). Recent climate change in the Arctic and its impact on contaminant pathways and interpretation of temporal trend data. Sci. Total Environ. 342, 5-86. doi: 10.1016/j.scitotenv.2004.12.059

Mahowald, N. (2011). Aerosol indirect effect on biogeochemical cycles and climate. Science 334, 794-796. doi: 10.1126/science.1207374

Maturilli, M., Herber, A., and Konig-Langlo, G. (2015). Surface radiation climatology for Ny-lesund, Svalbard (78.9A degrees N), basic observations for trend detection. Theor. Appl. Climatol. 120, 331-339. doi: 10.1007/s00704-014-1173-4

Meile, C., and Jones, C. (2016). "A mathematical perspective on microbial processes in Earth's biogeochemical cycles," in Mathematical Paradigms of Climate Science, eds F. Ancona, P. Cannarsa, C. Jones, and A. Portaluri (Cham: Springer International Publishing), 3-14.

Michelutti, N., Keatley, B. E., Brimble, S., Blais, J. M., Liu, H. J., Douglas, M. S., et al. (2009). Seabird-driven shifts in Arctic pond ecosystems. Proc. R. Soc. B. Biol. Sci. 276, 591-596. doi: 10.1098/rspb.2008.1103

Miller, A. W., and Ruiz, G. M. (2014). Arctic shipping and marine invaders. Nat. Clim. Chang. 4, 413-416. doi: 10.1038/nclimate2244

Mindl, B., Anesio, A. M., Meirer, K., Hodson, A. J., Laybourn-Parry, J., Sommaruga, R., et al. (2007). Factors influencing bacterial dynamics along a transect from supraglacial runoff to proglacial lakes of a high Arctic glacieri. FEMS Microbiol. Ecol. 59, 762. doi: 10.1111/j.1574-6941.2007.00295.x

Miniaci, C., Bunge, M., Duc, L., Edwards, I., Burgmann, H., and Zeyer, J. (2007). Effects of pioneering plants on microbial structures and functions in a glacier forefield. Biol. Fertil. Soils 44, 289-297. doi: 10.1007/s00374-007-0203-0

Moe, B., Stempniewicz, L., Jakubas, D., Angelier, F., Chastel, O., Dinessen, F., et al. (2009). Climate change and phenological responses of two seabird species breeding in the high-Arctic. Mar. Ecol. Prog. Ser. 393, 235-246. doi: $10.3354 / \mathrm{meps} 08222$

Moreau, M., Mercier, D., Laffly, D., and Roussel, E. (2008). Impacts of recent paraglacial dynamics on plant colonization: a case study on Midtre Lovenbreen foreland, Spitsbergen (79 degrees N). Geomorphology 95, 48-60. doi: 10.1016/j.geomorph.2006.07.031

Morgan-Kiss, R. M., Priscu, J. C., Pocock, T., Gudynaite-Savitch, L., and Huner, N. P. (2006). Adaptation and acclimation of photosynthetic microorganisms to permanently cold environments. Microbiol. Mol. Biol. Rev. 70, 222-252. doi: 10.1128/mmbr.70.1.222-252.2006

Moss, R. H., Edmonds, J. A., Hibbard, K. A., Manning, M. R., Rose, S. K., van Vuuren, D. P., et al. (2010). The next generation of scenarios for climate change research and assessment. Nature 463, 747-756. doi: 10.1038/nature08823

Nadelhoffer, K. J., Emmett, B. A., Gundersen, P., Kjonaas, O. J., Koopmans, C. J., Schleppi, P., et al. (1999). Nitrogen deposition makes a minor contribution to carbon sequestration in temperate forests. Nature 398, 145-148. doi: $10.1038 / 18205$

Newsham, K. K., Hopkins, D. W., Carvalhais, L. C., Fretwell, P. T., Rushton, S. P., Odonnell, A. G., et al. (2016). Relationship between soil fungal diversity and temperature in the maritime Antarctic. Nat. Clim. Chang. 6, 182-186. doi: $10.1038 /$ nclimate 2806

Oechel, W. C., Hastings, S. J., Vourlitis, G., Jenkins, M., Riechers, G., and Grulke, N. (1993). Recent change of Arctic Tundra ecosystems from a net carbon-dioxide sink to a source. Nature 361, 520-523. doi: 10.1038/361 $520 \mathrm{a} 0$

Oechel, W. C., Vourlitis, G. L., Hastings, S. J., Zulueta, R. C., Hinzman, L., and Kane, D. (2000). Acclimation of ecosystem CO2 exchange in the Alaskan Arctic in response to decadal climate warming. Nature 406, 978-981. doi: $10.1038 / 35023137$

Okuda, M., Imura, S., and Tanemura, M. (2007). Microtopographic analysis of plant distribution in polar desert. Polar Sci. 1, 113-120. doi: 10.1016/j.polar.2007.09.001

Okuda, M., Imura, S., and Tanemura, M. (2011). Microtopographic properties of sparse moss vegetation in the Antarctic polar desert. Polar Sci. 5, 432-439. doi: 10.1016/j.polar.2011.10.001

Overland, J. E., Wang, M. Y., Walsh, J. E., and Stroeve, J. C. (2014). Future Arctic climate changes: adaptation and mitigation time scales. Earths Future 2, 68-74. doi: 10.1002/2013EF000162

Paul, F., Frey, H., and Le Bris, R. (2011). A new glacier inventory for the European Alps from Landsat TM scenes of 2003: challenges and results. Ann. Glaciol. 52, 144-152. doi: 10.3189/172756411799096295

Peters, G. P., Nilssen, T. B., Lindholt, L., Eide, M. S., Glomsrod, S., Eide, L. I., et al. (2011). Future emissions from shipping and petroleum activities in the Arctic. Atmos. Chem. Phys. 11, 5305-5320. doi: 10.5194/acp-11-5305-2011

Prietzel, J., Dumig, A., Wu, Y. H., Zhou, J., and Klysubun, W. (2013). Synchrotronbased P K-edge XANES spectroscopy reveals rapid changes of phosphorus speciation in the topsoil of two glacier foreland chronosequences. Geochim. Cosmochim. Acta 108, 154-171. doi: 10.1016/j.gca.2013.01.029 
Roberts, T. J., Hodson, A., Evans, C. D., and Holmen, K. (2010). Modelling the impacts of a nitrogen pollution event on the biogeochemistry of an Arctic glacier. Ann. Glaciol. 51, 163-170. doi: 10.3189/172756411795931949

Sattin, S. R., Cleveland, C. C., Hood, E., Reed, S. C., King, A. J., Schmidt, S. K., et al. (2009). Functional shifts in unvegetated, perhumid, recently-deglaciated soils do not correlate with shifts in soil bacterial community composition. J. Microbiol. 47, 673-681. doi: 10.1007/s12275-009-0194-7

Scheer, C., Grace, P., and Rowlings, D. (2016). Non-linear response of soil N2O emissions to nitrogen fertiliser in a cotton-fallow rotation in sub-tropical Australia. Soil Res. 54, 494-499. doi: 10.1071/SR14328

Schulz, S., Brankatschk, R., Dumig, A., Kogel-Knabner, I., Schloter, M., and Zeyer, J. (2013). The role of microorganisms at different stages of ecosystem development for soil formation. Biogeosciences 10, 3983-3996. doi: 10.5194/bg-10-3983-2013

Schutte, U. M., Abdo, Z., Bent, S. J., Williams, C. J., Schneider, G. M., Solheim, B., et al. (2009). Bacterial succession in a glacier foreland of the High Arctic. ISME J. 3, 1258-1268. doi: 10.1038/ismej.2009.71

Screen, J. A., and Simmonds, I. (2010). The central role of diminishing sea ice in recent Arctic temperature amplification. Nature 464, 1334-1337. doi: 10.1038/nature09051

Serreze, M. C., Walsh, J. E., Chapin, F. S., Osterkamp, T., Dyurgerov, M., Romanovsky, V., et al. (2000). Observational evidence of recent change in the northern high-latitude environment. Clim. Change 46, 159-207. doi: 10.1023/A:1005504031923

Shcherbak, I., Millar, N., and Robertson, G. P. (2014). Global metaanalysis of the nonlinear response of soil nitrous oxide $\left(\mathrm{N}_{2} \mathrm{O}\right)$ emissions to fertilizer nitrogen. Proc. Natl. Acad. Sci. U.S.A. 111, 9199-9204. doi: 10.1073/pnas.1322434111

Singer, G. A., Fasching, C., Wilhelm, L., Niggemann, J., Steier, P., Dittmar, T., et al. (2012). Biogeochemically diverse organic matter in Alpine glaciers and its downstream fate. Nat. Geosci. 5, 710-714. doi: 10.1038/ngeo1581

Sistla, S. A., Moore, J. C., Simpson, R. T., Gough, L., Shaver, G. R., and Schimel, J. P. (2013). Long-term warming restructures Arctic tundra without changing net soil carbon storage. Nature 497, 615-618. doi: 10.1038/nature12129

Stibal, M., Elster, J., Sabacka, M., and Kastovska, K. (2007). Seasonal and diel changes in photosynthetic activity of the snow alga Chlamydomonas nivalis (Chlorophyceae) from Svalbard determined by pulse amplitude modulation fluorometry. FEMS Microbiol. Ecol. 59, 265-273. doi: 10.1111/j.1574-6941.2006.00264.x

Stibal, M., Sabacka, M., and Zarsky, J. (2012). Biological processes on glacier and ice sheet surfaces. Nat. Geosci. 5, 771-774. doi: 10.1038/ngeo1611

Stocker, T. F., Qin, D., Plattner, G. K., Tignor, M., Allen, S. K., Boschung, J., et al. (2013). IPCC, 2013: Climate Change 2013: The Physical Science Basis. Contribution of Working Group I to the Fifth Assessment Report of the Intergovernmental Panel on Climate Change. Cambridge; New York, NY: Cambridge University Press.
Strauss, S. L., Garcia-Pichel, F., and Day, T. A. (2012). Soil microbial carbon and nitrogen transformations at a glacial foreland on Anvers Island, Antarctic Peninsula. Polar Biol. 35, 1459-1471. doi: 10.1007/s00300-012-1184-5

Takeuchi, N., Fujita, K., Nakazawa, F., Matoba, S., Nakawo, M., and Rana, B. (2009). A snow algal community on the surface and in an ice core of RikhaSamba Glacier in Western Nepali Himalayas. Bull. Glaciol. Res. 27, 25-35. doi: 10.1657/1523-0430(2004)036

Vanderpuye, A., Arve, E., and Lennard, N. (2002). Plant communities along environmental gradients of high-arctic mires in Sassendalen, Svalbard. J. Veg. Sci. 13, 875-884. doi: 10.1111/j.1654-1103.2002.tb02117.x

van der Wal, R., and Stien, A. (2014). High-arctic plants like it hot: a longterm investigation of between-year variability in plant biomass. Ecology 95, 3414-3427. doi: 10.1890/14-0533.1

Vincent, W. F. (2010). Microbial ecosystem responses to rapid climate change in the Arctic. ISME J. 4, 1089-1090. doi: 10.1038/ismej.2010.108

Ware, C., Berge, J., Sundet, J. H., Kirkpatrick, J. B., Coutts, A. D. M., Jelmert, A., et al. (2014). Climate change, non-indigenous species and shipping: assessing the risk of species introduction to a high-Arctic archipelago. Divers. Distrib. 20, 10-19. doi: 10.1111/ddi.12117

Yergeau, E., Bokhorst, S., Kang, S., Zhou, J., Greer, C. W., Aerts, R. et al. (2012). Shifts in soil microorganisms in response to warming are consistent across a range of Antarctic environments. ISME J. 6, 692-702. doi: 10.1038/ismej.2011.124

Zaehle, S., and Friend, A. D. (2010). Carbon and nitrogen cycle dynamics in the O-CN land surface model: 1. Model description, site-scale evaluation, and sensitivity to parameter estimates. Glob. Biogeochem. Cycles 24:GB1005. doi: 10.1029/2009gb003521

Zhou, X., Zhang, Y., and Downing, A. (2012). Non-linear response of microbial activity across a gradient of nitrogen addition to a soil from the Gurbantunggut Desert, northwestern China. Soil Biol. Biochem. 47, 67-77. doi: 10.1016/j.soilbio.2011.05.012

Zumsteg, A., Luster, J., Goransson, H., Smittenberg, R. H., Brunner, I., Bernasconi, S. M., et al. (2012). Bacterial, Archaeal and fungal succession in the forefield of a Receding Glacier. Microb. Ecol. 63, 552-564. doi: 10.1007/s00248-011-9991-8

Conflict of Interest Statement: The authors declare that the research was conducted in the absence of any commercial or financial relationships that could be construed as a potential conflict of interest.

Copyright (c) 2017 Bradley, Anesio and Arndt. This is an open-access article distributed under the terms of the Creative Commons Attribution License (CC BY). The use, distribution or reproduction in other forums is permitted, provided the original author(s) or licensor are credited and that the original publication in this journal is cited, in accordance with accepted academic practice. No use, distribution or reproduction is permitted which does not comply with these terms. 